\title{
Mapping Memory: Myth, History, and Liminality in Harlem and the Bronx
}

\author{
David Andrew Laidler \\ Wellington, New Zealand

\begin{abstract}
A Thesis submitted to Victoria University of Wellington
in Candidacy for the Degree of Master of Music
\end{abstract}

Te Kōkī New Zealand School of Music

March 2016 


\begin{abstract}
Mapping Memory: Myth, History, and Liminality in Harlem and the Bronx
\end{abstract}

\author{
David Andrew Laidler \\ (Under the supervision of David Cosper \\ and Kimberly Cannady)
}

The relationship between notions of 'history' and 'myth' is a familiar dilemma within the field of historiography. As this thesis will seek to demonstrate, myth - defined here as evaluative representations of the past to suit demands of the present - is virtually indistinguishable from history, insofar as both are constructed from the same raw materials: subjective remembrances. Through an examination of mythical representations of physical places, this thesis will present a model to explain how myth is constructed, thereby emphasising the intimate and problematic relationship between the aforementioned categories.

In short, myth making occurs when memories travel through liminal space from one individual to the next, with said liminal points allowing for degradation and transmutation. The further along one is in the chain, the more one is dependent on myth. Through electing to focus on two such locales that have been of particular interest to me - Harlem during the jazz age and The Bronx during the origins of hip hop - I was able to adopt an auto-ethnographic perspective, gaining insight into the extent to which my understanding was dependent on a series of compounding representations. Further, these areas also draw attention to how such representation can broaden or localise, depending on the myth and the purpose of its invocation. In different contexts and different historical narratives, different areas within New York City have been subjected to the same process, which can account for the pervasive idea of 'New York' that continues to circulate. 


\section{Acknowledgments}

I would first like to thank David and Kim for all your advice and, more importantly, for always staying calm when I struggled to.

To the NZSM and VUW for having enough trust in my idea to help with my trip.

To Tim, Katie, and Ailsa for just being generally smart folks who always provided a much-needed change in perspective.

To Peter, Alex, and Grandmaster Caz for taking the time to talk with me and helping to make New York a less bewildering place.

To my office-mates, and now my dear friends Hannah and Elyse. Ploughing through books is always easier with you guys around.

Most of all though, I want to thank my family: Mum, Dad, Michael, Mark, Margaret, Gay, and Dennis. Without your constant and unwavering support it is unlikely I would have made it to this point. 
Table of Contents

Introduction. .5

Methodology.............................................9

Core Concepts: Myth, Memory, Liminality............9

(Auto)Ethnography............................14

Roadmap.......................................15

Congo Square as a Site of Cultural Memory...............16

Chapter One: Harlem Jazz Past and Present..................................... 23

Harlem in Jazz Historiography ........................23

The Emergence of Harlem............................25

The Harlem Renaissance.................................28

Harlem in the Present: When Representations Collide.......32

Conclusion......................................... 38

Chapter Two: The Bronx and the Origins of Hip Hop...........................40

The Bronx is Burning.................................41

Space, Place, and Borders: Dub and Disco..............45

Dub in New York....................47

Hip Hop and Disco: Forgotten Links..51

Disco and Hip Hop Come Together...53

Conclusion............................................55

Final Conclusion.......................................................56

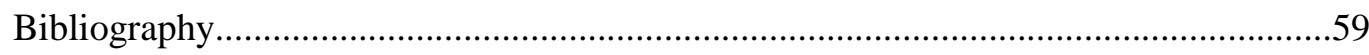


"Who controls the past controls the future: Who controls the present controls the past."

- $\quad$ George Orwell, 1984

When we think of myths, we are inclined to think of lies, falsehoods, and misconceptions. These are fanciful tales depicting engaging but far-fetched theories about the creation of the universe, humankind, and ensuing societal structures. Or perhaps they are more mundane, the kind that a couple of kooky scientists on the Discovery Channel can challenge on a weekly basis. History, by contrast, is rational and robust, concerned with verifiable facts and unconcerned with the fictitious narratives that the word 'myth' is thought to represent. But scholars such as Hayden White and Jennifer Frost ${ }^{1}$ have sought to problematize this conception of history; presenting the past involves strategy and editing, it necessitates careful and deliberate decisions regarding inclusion and exclusion. The final product of this subjective process is the historical narrative. The history of music is no exception. This complex and multifaceted discourse is broken down and separated by style or era, with the personal tales of triumph and tragedy of a select few individuals interwoven and often inextricably bound to these problematic categories. This process of composing the past into a neat and coherent trajectory complete with a beginning, middle, and end and conveniently punctuated by conceptual borders that distinguish canonised individuals and time periods is not a neutral account of the past, but an evaluative gesture with real ramifications in the present.

Scholarly perspectives on myth reveal certain similarities. As argued by the likes of religious studies specialist Bruce Lincoln and musicologist Christopher Small, 'myth' in this context is not necessarily that which is patently untrue, but rather that which validates contemporary values and sentiments. ${ }^{2}$ Myth's complicated relationship with material reality is further demonstrated by philosopher and literary critic Roland Barthes, who suggests that "myth hides nothing: its function is to distort, not make disappear". ${ }^{3}$ Further, both myth and history are more often than not presented in the form of a narrative. ${ }^{4}$ Elie Wiesel, a scholar of myth and history, also provides useful insight on the matter, arguing "there is myth in history

\footnotetext{
${ }^{1}$ Hayden White, 'The Value of Narrativity in the Representation of Reality', Critical Inquiry 7/1 (1980), 27.; Jennifer Frost, 'Using "Master Narratives" to Teach History: The Case of the Civil Rights Movement', The History Teacher 45/3 (2012), 437.

${ }^{2}$ Bruce Lincoln, Discourse and the Construction of Society (Chicago: University of Chicago Press, 1989), 25.; Christopher Small, Musicking: the Meanings of Performing and Listening (Connecticut: Wesleyan University Press, 1998), 100.

${ }^{3}$ Roland Barthes, Mythologies, trans. Annette Lavers (New York: Hill and Wang, 1972), 121.

4 James Wiggins, 'History as Narrative', in Myth and the Crisis of Historical Consciousness, ed. Lee W. Gibbs and W. Taylor Stevenson (Missoula: Scholars Press, 1975), 77.
} 
just as there is history in myth". ${ }^{5}$ Taken together, these ideas illustrate the central argument posed in this thesis: that 'myth' and 'history' are not discrete ideas, but are rather two epistemological tools in a constant and complex conversation with one another. This contention was derived not only from the mode of presentation familiar to both categories, that of the narrative, but also from the raw materials necessary for the construction of such narratives. In short, I argue that both history and myth draw on subjective remembrances in their composition, remembrances that are open to degradation and distortion. ${ }^{6}$

This notion will be demonstrated through the application of a theoretical model that builds on the work of scholars such as Barthes and Wiesel, demonstrating the interplay between myth, history, memory, and liminality, or a 'state of in between.' Memories, by their very nature, are malleable and subject to degradation over time. What's more, this degradation and malleability can be strategic, certain aspects of a memory can be omitted, perhaps forgotten or 're-remembered' to suit a particular situation. ${ }^{7}$ The problem of constructing and articulating history therefore, among other things, is that it is intimately dependent on a collection of subjective memories, not just of the historian's so-called 'informants,' but also their own. This thesis will seek to argue, therefore, that it is during the transferal of memories where myth-making takes place. This transitional or liminal phase occurs multiple times in the collection and subsequent writing up of history: during the act of recalling a memory and translating it into spoken words; the other party receiving the memory and storing it; the second party's recollection of the original recollection; and the ensuing conversion of it into a historical document. In less convoluted terms, mythmaking occurs during the transferral of subjective remembrances from one individual to the next, but it is most effective when 'auto-noetic' memory, or the experiential memory of individuals, becomes 'semantic memory,' immortalised as history in books, films and so on, given that these artefacts are more farreaching, and so provide more liminal space for the memory to travel through. In effect our understanding of the past is dependent on a series of compounded representations, representations that can be augmented at any one of the multiple liminal phases described above. The strength of a given myth, therefore, depends on one's proximity to the initial remembrance. The more removed one is from said remembrance, the more transformative spaces the memory has travelled through.

The lingering question is where to apply such a model. The answer lies, in part, within the last point raised above: that of proximity. Although scholars such as White and Frost concerns themselves primarily with issues surrounding chronology, it is not just past events and individuals that are retrospectively

\footnotetext{
${ }^{5}$ Elie Wiesel, 'Myth and History', in Myth, Symbol, and Reality, ed. Alan M. Olson (Indiana: University of Notre Dame Press, 1980), 20.

${ }^{6}$ Maria G. Cattell, Jacob J. Climo, 'Meaning in Social Memory and History,' in Social Memory and History:

Anthropological Perspectives, ed. Maria G. Cattel, Jacob J. Climo (California: Altamira Press, 2002), 1.

7 Ibid.
} 
subjected to the myth-making process, but also the physical places in which such events occur. ${ }^{8}$ Thanks to the activity (in this case, musical activity) of individuals within their respective contexts, these geographical locales take on a mythical character, becoming ideologically enriched representations of place that loom large in historical discourse, overshadowing musical activities in areas outside this geographical canon. Further, these impressions persist due to one's distance from the lived experience of the past.

My application of place, therefore, is based on two different conceptions. The first refers to material places and the evaluative gestures that manipulate the various connotations and associations that get attached to the area. The second refers to one's place relative to the memories that travel from those locales. The idea of distance as used in this thesis is also broadly conceived; whether temporal, cultural, or geographical, the further away we are from original context, the more potent the myth becomes. A focus on physical places is particularly fruitful for exploring this last point. Two of the above three conceptions of distance (cultural and geographical) are mutable to a degree; by physically going to these places, as I did for three weeks in February of 2015, one is able to experience a destabilisation of myth as lived experience in the present clashes with inherited representations.

To explore the premises outlined above, I have crafted a comparative study of two such areas that have enjoyed a privileged position is their respective musical and temporal contexts: Harlem during the jazz age and the Bronx during the advent of hip hop. One of the primary reasons for this, beyond a personal preference that has persisted for some time, is the two areas' relative proximity to one another. This is an especially important point; as will become clear, the entire area of New York has also been heavily mythologised, primarily due to the cultural activities that occurred within more specific locales throughout the city. One need only witness the proliferation of clothing bearing the words (and occasionally associated imagery) "New York," "Brooklyn," or even "Williamsburg" to appreciate the mythical power the city of New York wields.

While both Harlem and the Bronx share certain characteristics in their mythologised manifestation (for example the 'founding father' myth, an important concept in understanding myth and its application to geographical places), the specific myths that get attached to these places can often harbour different functions, emphasising the strategic nature of history construction. For example, Harlem is not the ground zero of jazz, but the narratives (and the language applied in those narratives) that have been retrospectively attached to the "capital of Black America" arguably overshadow jazz practise in other

\footnotetext{
${ }^{8}$ Maria G. Cattell, Jacob J. Climo, 'Meaning in Social Memory and History,' in Social Memory and History: Anthropological Perspectives, ed. Maria G. Cattel, Jacob J. Climo (California: Altamira Press, 2002), 21.
} 
places like $52^{\text {nd }}$ Street or the West Village. The South Bronx, on the other hand, is seen as a distinct point of origin. Various sources on the subject do mention potential antecedents, but a conceptual line in the sand has been drawn between those antecedents and what was happening in the Bronx. This last point raises another important concept for the present discussion: that of borders. Earlier in the Introduction I alluded to the ways in which conceptual borders are deployed to distinguish supposedly discrete eras or styles, but through the adoption of a focus on physical places, it becomes apparent that geographical borders can be used in much the same way. In the case of the Bronx, for example, boundaries between both genre and borough are directly implicated in the narrative surrounding the development of the music. Through the reiteration of said narrative through various channels such as books, documentaries, and journal articles, the story becomes codified as the 'master narrative' of the origins of hip hop.

Another core reason for my selection in musical and geographical contexts concerns particularities in the reception of African American music making more generally. Ronald Radano, a scholar of African American music, describes the ways in which music, specifically, helped to foster white ideologies concerning racial difference. ${ }^{9}$ He writes: "The perception of musical difference had grown so thoroughly racialized that music had come to epitomise racial differences generally, informing opinion across the racial divide." 10 This musical difference he refers to is the supposed "natural musicality" that was thought by some white observers to be inherent to the African American slave population. ${ }^{11}$ This notion of the "entrancing power" and "sublime spirit" of the music that "test the limits of white comprehension" 12 arguably amounts to mythical representation strengthened by distance, in this case cultural. Put against the backdrop of oppressive and horrid social and economic conditions, the abovementioned observations (themselves subjective remembrances) set off the 'master narrative' of African American music history more broadly: the monolithic, unwavering essence of "blackness"13 that supposedly runs throughout. This thesis builds on his work through the application of the model outlined above that 'history,' African American or otherwise, borrows heavily from myth in its construction, further emphasising the intimate relationship between these two concepts.

The final reason behind my selection is a specific musical practice that is arguably common to all genres explored in this thesis: the creative borrowing of sounds from the musical past and resituating them in a new context. This is not to fall into the trap outlined above by Radano, rather, as Guthrie Ramsey suggests: "For all our academic enthusiasm to deconstruct monolithic impulses in the name of a diverse

\footnotetext{
${ }^{9}$ Ronald Radano, Lying up a Nation: Race and Black Music (Chicago: University of Chicago Press, 2003$), 9$.

${ }^{10} \mathrm{Ibid}$

11 lbid., 179.

12 Ibid., 180-181.

13 Ibid., 3.
} 
blackness, we must recognise that some cultural markers have remained remarkably stable in practice, albeit not in their precise meanings." ${ }^{14}$ A focus on performative similarities will be particularly fruitful in Chapter 2, the case study on the Bronx, as it demonstrates the mutability of borders separating genres, stimulating a need to draw on geographical ones. But this practice also serves as an interesting musical parallel to the process of mythologizing the past; artefacts of the past are strategically selected to suit demands in the present. Further, Ramsey also argues that "these cultural forms, such as tales, stories, and music (especially the performative aspects of each) function as reservoirs where cultural memories reside." ${ }^{15}$ Here Ramsey makes reference to another conception of memory to be applied throughout the thesis: cultural memory. A contentious term with a multiplicity of names, cultural, social, or collective memory is defined by French sociologist Maurice Halbwachs, as "agreed upon versions of the past, versions constructed through communication, not private remembrance." 16 Practises like playing jazz standards, spinning old records, and remixing, therefore, help to illustrate the intimate relationship between memory, myth, and history.

\section{Methodology}

The first step in constructing this project was exploring the relationships and similarities between my core theoretical frameworks: myth, history, memory, and liminality. This process, which allowed me to come to the conclusion that myth and history are more closely entwined than previously realised, given that both stem from remembrances that are funnelled through liminal space, will be outlined in the paragraphs that follow. This was then supplemented with fieldwork I conducted in New York City for three weeks in February of 2015. The fieldwork involved interviews, going to gigs, and generally experiencing the space. It is this last component that enriched my conception of distance; not only is the potency of myth dependent on the number of liminal spaces a memory travels through, but also how culturally, temporally, and geographically removed the eventual recipient is. Much of my fieldwork, therefore, took on a reflexive character: through an examination of the ways in which the areas gained my interest, and my personal expectations derived from that interest, I experienced a clash in representation between the narratives I had inherited and my lived experience.

\section{Core Concepts: Myth, Memory, Liminality}

\footnotetext{
${ }^{14}$ Guthrie P. Ramsey, Jr., Race Music: Black Cultures from Bebop to Hip Hop (California: University of California Press, 2003), 41.

15 Ibid., 33.

${ }^{16}$ Maria G. Cattell, Jacob J. Climo, 'Meaning in Social Memory and History,' in Social Memory and History: Anthropological Perspectives, ed. Maria G. Cattel, Jacob J. Climo (California: Altamira Press, 2002), 4.
} 
My understanding of myth was primarily informed by Bruce Lincoln. In his book Discourse and the Construction of Society, Lincoln painstakingly differentiates myth from other narrative styles like fable or legend, terms that have often be used interchangeably. According to Lincoln, narratives that we would refer to as 'history' must meet the following criteria: “(1) a numerically specified position in the sequence of elapsed time can be affixed to them; (2) written sources attest to them; and (3) their only significant actors are human." ${ }^{\prime 17}$ The primary concern with this model is it only concerns itself with the actual content, ignoring the interpretive powers of those that disseminate said content, and those that receive it.

As something of a corrective, Lincoln suggests the following:

Some narratives make no truth-claims at all, but rather present themselves and are accepted as fictions pure and simple: These I propose to call Fable. Others, in differing styles and degrees, purport to offer accurate accounts of past events. But of the stories that make such truth-claims, only some have sufficient persuasive power to gain general acceptance, and the others - those that, in the opinion of their primary audience, lack credibility - I shall classify as Legend, calling those that do have credibility, History... Beyond this, there is one further category, and that a crucial one: Myth - by which I designate that small class of stories that possess both credibility and authority (emphasis in the original). ${ }^{18}$

This notion of authority is key, and one that that has been integral to my understanding of myth and its manipulative power. Simply put, to say a narrative possesses authority in this context is to say, as mentioned previously, that this is a value projection that informs experience in the present. Lincoln credits the work of Bronislaw Malinowski and Clifford Geertz in reaching this conclusion insofar as the former characterised origin myths as a "pragmatic charter" 19 for contemporary hegemonic structures while the latter conceptualised religion as both a "model for" and a "model of" society. ${ }^{20}$ Myth supposedly differs from history in that rather than simply purporting truth-claims, it purports a "paradigmatic truth," a contention as to how something should be understood. Mythical narratives or, indeed, representations of places are not neutral therefore, but are underpinned by assumptions and ideology. Christopher Small reiterates this by arguing:

A myth, therefore, no matter how ancient its origins or subject matter, is always concerned with contemporary relationships, here and now. Whether or not it is historically true is beside the point; its value lies not in its truth to any actual past whose reality we can establish or disprove but in its present usefulness as guide to values and conduct. ${ }^{21}$

\footnotetext{
${ }^{17}$ Bruce Lincoln, Discourse and the Construction of Society (Chicago: University of Chicago Press, 1989), 24.

18 Ibid.

${ }^{19}$ Bronislaw Malinowski, 'Myth in Primitive Psychology', in Malinowski and the Work of Myth, ed. Ivan Strenski (Princeton: Princeton University Press, 1992), 82.

${ }^{20}$ Bruce Lincoln, 24.

${ }^{21}$ Christopher Small, 100.
} 
The over-arching feature of myth to be explored in this context then, is its capacity to ideologically inform present day experience of the past, "mobilising social groupings" ${ }^{2}$ through retroactively compartmentalising the past into neat pockets of styles, eras, or in my case, places. In exploring the origins of hip hop, for example, there seemed to be a conceptual grey area as to where disco ended and hip hop began. The remembrances of some of the 'founding fathers,' however, leads one to the assumption that they were entirely separate musical movements. These sentiments imply a compartmentalisation not just in terms of time, but also geography. Other artists working outside of the Bronx who shared a number of performative features with the likes of Kool Herc, Grandmaster Flash, and Afrika Bambaata continue to be excluded from the discourse on the basis that that which they were doing was closer to disco, or at the very least, not hip hop. Here then we have a case of an articulation of paradigmatic truth; artists such as King Charles, and the Disco Twins were ostensibly not the 'founding fathers' of hip hop because their music runs counter to what hip hop is, or what it should be. In articulating such remembrances, actors effectively drew conceptual boundaries, between disco and hip hop, and between the Bronx and the rest of New York.

The abovementioned quote offered by Lincoln suggets that he distinctly separated 'myth' from 'history,' insofar as the latter possesses “credibility." ${ }^{23}$ This was my point of departure. The next step was to explore the key ideas surrounding historiography. Turning back to Barthes, he argues that myth can be thought of as a type of 'speech.' 24 This idea naturally plays into my contention that myth-making occurs during the transferal of subjective remembrances, but his particular definition of speech has further implications. He writes: "speech of this kind is a message. It is therefore by no means confined to oral speech. It can consist of modes of writing or of representations". ${ }^{25}$ If written discourse can be conceptualised as a mythologised mode of 'speech', then surely books that purport to describe the 'history' of a given subject are no exception. Hayden White, a philosopher of history, further problematizes the distinction between these terms by asking the pertinent question "does the world really present itself to perception in the form of well-made stories, with central subjects, beginnings, middles, and ends, and a coherence that permits us to see 'the end' in every beginning?"26 This rhetorical question, along with the title, 'The Value of Narrativity in the Representation of Reality' revealed to me the similarities in scholarly approaches to both myth and history. In both cases, one is forced to rely on representation. Jennifer Frost, mentioned earlier in the introduction, also makes the point that in the

\footnotetext{
22 Bruce Lincoln, 24.

23 Ibid.

${ }^{24}$ Roland Barthes, 110.

25 Ibid.

${ }^{26}$ Hayden White, 'The Value of Narrativity in the Representation of Reality', Critical Inquiry 7/1 (1980), 27.
} 
construction of 'master narratives,' historians make a choice as to where to begin and end their stories, ${ }^{27}$ implying agency and thus, like myth, underpinned by value and ideology.

Memory, as has already been alluded to, proved to be a challenging concept to grapple with, considering the many terms and usages associated with it in an academic context. Social memory, collective memory, or cultural memory have seemingly been used interchangeably, particularly since the 1980s, when the concept began to gain traction. Astrid Erll, in her edited collection, suggests 'cultural memory' as a more appropriate tool, defining it as "the interplay between past and present in socio-cultural contexts." Already it becomes apparent that cultural memory is underpinned by myth, insofar as the latter involves representations of the past with implications in the present. Informed by Clifford Geertz and his conception of culture as a particular way of life governed by "self-spun webs of significance," 28 cultural memory appears to be a more all-encompassing definition. She writes:

According to anthropological and semiotic theories, culture can be seen as a three dimensional framework, comprising social (people, social relations, institutions), material (artefacts and media), and mental aspects (culturally derived ways of thinking, mentalities) (cf. Posner). Understood in this way, 'cultural memory' can serve as an umbrella term which comprises 'social memory' (the starting point for memory research in the social sciences), 'material or medial memory' (the focus of interest in literary and media studies), and 'mental or cognitive memory' (the field of expertise in psychology and the neurosciences). This neat distinction is of course merely a heuristic tool. In reality, all three dimensions are involved in the making of cultural memories. ${ }^{29}$

Following Erll's example, I will be using the term 'cultural memory' throughout the thesis. Of interest to me is also the interplay between individual memory and cultural memory. As mentioned previously, the construction of a cultural memory is contingent on the collection of subjective memories from disparate individuals. But as Fabian points out, individual memory, in the conceptual sense, is problematic. He writes: "the problem with a notion as plausible as collective (read cultural) memory is that its opposite, 'individual memory,' is, strictly speaking, as implausible, indeed impossible as a 'monologue' in the strict sense of the word." ${ }^{30}$ This issue, one again, stems from the variety of contexts in which the term is used. Fabian goes on to say:

Looming behind the collective individual distinction is another one which we need to make if we want to tackle what may be the most pervasive conceptual and terminological problem in talk about memory: the cognitive verses the narrative understanding of the term. As a cognitive faculty memory can only be

\footnotetext{
27 Jennifer Frost, 'Using "Master Narratives" to Teach History: The Case of the Civil Rights Movement', The History Teacher 45/3 (2012), 440.

${ }^{28}$ Clifford Geertz, The Interpretation of Cultures: Selected Essays (New York: Basic Books, 1973), 3.

${ }^{29}$ Astrid Errl, 'Cultural Memory Studies: An Introduction,' in Cultural Memory Studies: an International and Interdisciplinary Handbook, ed. Astrid Erll, Ansgar Nünning (Berlin: Walter de Gruyter GmbH \& Co., 2008$), 4$. 30 Johannes Fabian, Memory Against Culture: Arguments and Reminders (Durham: Duke University Press, 2007),
} 93. 
attributed to individual minds (or brains); in that sense collectivities cannot remember. As a social practice, memory is a communicative practice; all narrated memory is in that sense collective. ${ }^{31}$

To extrapolate on this point, I would argue that not only is cultural memory dependent on individual memory for its conception, but in turn individual memories are informed by cultural memory. Since all memories occur in socio-cultural contexts, and require social mechanisms such as language to be expressed, an individual's memory, of say, a physical place, can be manipulated by the cultural memory surrounding it. This is particularly pertinent when we consider the role of distance in myth making and cultural memory. If we are to accept my contention that cultural memory is derived through the shifting of a given memory through liminal space from one individual to the next, then such memories are able to be experienced vicariously, ${ }^{32}$ removed from the original context in which the memory occurred. My memory of Harlem, for example, was shaped by various media representations or 'modes of speech' as Barthes would phrase it, and so my individual memory of the place was manipulated by cultural memory.

Liminality, from the Latin word Limen, literally means "threshold" or a state of in between. The usage of the term in social sciences first appeared in 1909 in Arnold Van Gennep's Rites de Passage. However Victor Turner, having picked up where Van Gennep left off, is arguably the most well-known and revered scholar who looked closely at the concept and so it is from his seminal essay "Betwixt and Between: The Liminal Period in Rites of Passage" that I will be drawing from here. In the essay he outlined three key phases that occur during these rites, in which individual (or collective, depending on the rite) identities are temporarily broken down, only to be reconstructed as a newly initiated member of the community. The three phases are as follows: "Separation," which refers to the state of being just prior to the initiation rite. This phase, in its anthropological usage, involves a given identity being pulled from its initial context, ready to be deconstructed. ${ }^{33}$ The next phase outlined by Turner is the liminal period. This point marks the conceptual threshold in which traditional social order is no longer a given and established identities are broken down to allow for their reconstruction and ultimately their reintroduction into society. ${ }^{34}$ The final stage, the "aggregation" phase, involves the re-establishment of pre-existing social hierarchies. The central participant, perhaps a child undertaking an initiation rite into adulthood, is reintroduced into society, their social identity having been reconstructed according to culturally specific ideologies. ${ }^{35}$

\footnotetext{
${ }^{31}$ Johannes Fabian, Memory Against Culture: Arguments and Reminders (Durham: Duke University Press, 2007), 93.

${ }^{32}$ Maria G. Cattell, Jacob J. Climo, 'Meaning in Social Memory and History,' in Social Memory and History: Anthropological Perspectives, ed. Maria G. Cattel, Jacob J. Climo (California: Altamira Press, 2002), 12.

${ }^{33}$ Victor Turner, 'Betwixt and Between: The Liminal Period in Rites of Passage', in Betwixt and Between: Patterns of Masculine and Feminine Initiation, ed. Louise Carus Mahdi, Steven Foster, and Meredith Little (Illinois: Open Court Publishing Company, 1987), 5.

${ }^{34} \mathrm{Ibid}$.

${ }^{35} \mathrm{lbid}$.
} 
But this middle phase, the liminal or transitional phase, also serves as perhaps the greatest point of departure in my usage of the term as opposed to Van Gennep's or Turner's. Van Gennep and Turner are generally concerned with the identity of human individuals relative to the society in which they live. Further, these changes in identity occur during a pre-established ritual or ceremony ${ }^{36}$ which in turn implies an awareness of the transformation taking place, and the reasoning behind it. My conception of liminality, while concerned with memories as opposed to identity, concerns a series of processes that, while consistent, largely go unnoticed by participants. The core facet of liminality that I applied was the transformative potential that exists within these thresholds. Memories, in this case representations of place, shift from one subjective agent to the next. The more liminal phases a given memory has to shift through, the more mythologised it becomes. In the process these representations are subject to degradation and permutation, both in the initial storage of the memory, and in the subsequent recollection and re-articulation to the next subjective agent. And while these representations can be deliberately reremembered (or crucial aspects of it consciously forgotten) on the basis of a particular ideology, the agency required for such a process is not limited to an over-arching "master of ceremonies." In different contexts, the 'founding fathers,' scholars, journalists and the like all have the capacity to actively contribute to the myth-making process. It is thus the form of memory transferal that most clearly exemplifies the interplay between myth, history, and memory.

\section{Ethnography:}

Considering some of the core components of my argument, particularly surrounding distance, it seemed only appropriate that my research involve an ethnographic aspect. To that end, I was fortunate enough to travel to New York for three weeks in February, 2015. In the early stages of the project, I had envisaged my methods involving aspects of 'traditional' ethnography: participant-observation, informal conversation, formal interviews, and the like. During my time there I did employ these methods, but as the project developed, the parameters of my fieldwork more fully realised, and my notion of distance in relation to myth became more richly conceptualised. It became apparent that I should also adopt a reflexive perspective, exploring the myths as they had developed in my own mind, and comparing them to lived experience 'on the ground.'

In employing such a perspective, it becomes imperative to situate myself within the text, outlining my motivations and limitations during the research process. For it to be valuable, it needs to go beyond simply incorporating my experiences, "but to engage in critical reflection on one's relationship with

\footnotetext{
${ }^{36}$ Victor Turner, 5.
} 
others, as circumscribed by institutional practices and by history." ${ }^{37}$ As has been pointed out in the edited collection The Ethnographic Self as Resource, honesty is a key issue in disseminating my experiences in the name of academic inquiry. ${ }^{38}$ After all, how is the reader to know the self I represent in the text is an honest representation (if such a thing exists), and not self-consciously constructed to suit a certain function? Further, the memories of my experiences, like all memories explored in this thesis, are subject to the same degrees of degradation and distortion. Even my field notes are representations of events ${ }^{39}$ as they happen and in reviewing them they can become compounded with subsequent experiences since getting back. The point to stress here, and throughout the thesis as a whole, is in revisiting and describing past events, one is dependent on representation. The central aim then is to highlight this notion, that even in trying to draw attention to the process of myth making, I run the risk of perpetuating a myth of my own experiences. The best I can do, therefore, is to ensure that this point is made plain. Myth is an incredibly pervasive force in shaping our understanding of the past and no one, myself included, is immune.

My decision to adopt a more reflexive approach was motivated chiefly by the immense time constraints put upon me during my field work. As multiple parties warned me both before I left as well as upon my arrival, three weeks is not nearly enough time to accomplish the kind of ethnography I had initially planned. Due to a number of factors, not least of which is the outrageous financial cost of staying in New York, three weeks was all I could afford. At the time my research focus was very different, and in retrospect much too broad. An unintended benefit of these limitations, therefore, was the solidifying of both my topic and approach, including a reflexive lens. Another benefit to adopting such an approach is it allows a somewhat different mode of writing while making room for the author's unique voice. ${ }^{40}$ Heewon Chang argues that incorporating my "unique voicing" into the text is more engaging for the reader. This last point is useful to me in two ways. On the one hand, it ideally makes the thesis more enjoyable to read. One the other hand, it inadvertently emphasises the manipulative power narrative has in representing the past.

\footnotetext{
${ }^{37}$ Anne Meneley and Donna J. Young, 'Introduction - Auto-Ethnographies: The Anthropology of Academic Practices', in Auto-Ethnographies: The Anthropology of Academic Practices, ed. Anne Meneley and Donna J. Young (Toronto: Broadview Press Ltd., 2005), 7.

${ }_{38}$ Peter Collins, Anselma Gallinat, 'The Ethnographic Self as Resource: An Introduction', in The Ethnographic Self as Resource: Writing Memory and Experience into Ethnography, ed. Peter Collins and Anselma Gallinat (New York: Berghahn Books, 2010), 16.

39 Johannes Fabian, 'Ethnography and Memory', in Ethnographic Practice in the Present, ed. Marit Melhuus, Jon P. Mitchell, and Helena Wulff (New York: Berghahn Books, 2010), 17.

${ }^{40}$ Heewon Chang, Autoethnography as Method (California: Left Coast Press Inc., 2008 ), 52.
} 
My interview transcriptions have been carried out in a similar vein. Charlotte Aull Davis suggests that where possible, the interviewee's particular style of speech should be captured as accurately as possible. ${ }^{41}$ To that end, the transcription should read almost like a play, complete with pauses and repetitions. In regard to my observations, I have elected to follow the example set by Carolyn Ellis, insofar as they will be presented in the form of a narrative. ${ }^{42}$ Obviously there are dilemmas in presenting past events in such a manner, but again, the principle aim was engagement of the reader. Furthermore, Ellis argues that "stories should be both a subject and a method of social science research." ${ }^{23}$ In applying a narrative structure therefore, I am able to further illustrate the impossibility of escaping mythical representation.

\section{Roadmap:}

The first chapter will address the destabilisation of myth through clashing representations. Drawing heavily on my ethnographic experiences of Harlem, I will explore the cultural memory surrounding the area, the same cultural memory that fostered my interest in the borough. As has been touched on previously, these collections of subjective memories are not only the building blocks of myth, but also of history. I will demonstrate that the 'history' of Harlem is in fact steeped in myth, rendered as it is from remembrances and disseminated via a written mode of 'speech'. So if myths serve some ideological demand in the present, how can those that benefit from said myths look to circumscribe the various interpretive possibilities inherent in the myth-making process mentioned above? The second chapter, based on the Bronx, looks at methods to control the character of mythical representation, the overall goal being that these representations become, for all intents and purposes, taken as history as it is understood in general usage. The two key strategies to be discussed are frequent reiterations of the same narrative, the "master narrative," and the invocation (or breaking down) of borders, both physical and conceptual. The origins of hip hop provide a valuable case study for this idea for a number of reasons, not least of which is the fact that many of the supposed originators of the music are not only still alive but those that exercise the aforementioned strategies.

These individuals will be considered in the context of what I will be referring to as the 'founding father' myth. This problematic and gendered term is applied in this discussion in reference to a contentious documentary which was an early source of inspiration for this thesis. In short, I suggest certain individuals - 'founding fathers' - have a crucial role to play in the construction of myth, a role facilitated

\footnotetext{
${ }^{41}$ Charlotte Aull Davis, Reflexive Ethnography: A Guide to Researching Selves and Others (London: Routledge, 1999), 115.

${ }^{42}$ Carolyn Ellis, The Ethnographic I: A Methodological Novel About Autoethnography (Lanham: Altamira Press, 2004), 32.

${ }^{43} \mathrm{lbid}$.
} 
by their relative proximity to the relevant site of cultural memory. In the Bronx chapter, I recount my experiences with Grandmaster Caz of the Cold Crush Brothers, a B-Boy-come-DJ-come-MC who serves as a guide for a hip hop origins tour in New York City. 'In the game' since the mid-1970s, Grandmaster Caz is in a powerful position as far as hip hop history is concerned. As a Bronx native, he arguably has a vested interest in ensuring the continuing primacy of the area, and by extension, his own contribution to the music's development. In other instances, the 'founding father' is treated in much the same way as localities by outside parties: recollections of their various exploits are strategically interwoven within the narrative by future historians. Like the places in which these 'founding fathers' operated, the musical activities exercised by these mythologised characters provide useful boundaries, demarcating discrete genres and eras.

\section{Congo Square as a Site of Cultural Memory:}

The following section will seek to put the abovementioned frameworks to work. Though not a core case study in the thesis as a whole, Congo Square never-the-less serves as a useful demonstration of a mythologised site of cultural memory, not least because this tenacious narrative is among the first concerning African American music-making, and thus acts as a 'ground zero' for future narratives of the same topic, including the Bronx and Harlem.

In 1817 an area just outside New Orleans' French quarter previously known as Place Publique or Circus Square was formally recognised as an area where slaves could congregate on Sundays to make music together. In actual fact such gatherings had already taken place off and on over the years, but the formal recognition, and the renaming of the space to Congo Square, would have far reaching consequences for music historians in the decades to come. Just two years after the rebirth of the square, prominent architect Benjamin Latrobe penned an excited, though predictably exoticist account of what he saw there, remarking that the spectacle was "brutally savage." 44 And thus the long and complicated fascination with the square began.

For my purposes, Latrobe acts as, if not the first, then at the very least the first prominent, series of thresholds through which the memory of Congo Square was to travel. In effect, the myth of Congo Square began construction the moment the events he saw crossed the liminal point from an event in real time into his memory banks. The event would then become further mythologised upon the retrieval of the memory

\footnotetext{
${ }^{44}$ Ted Widmer 'The Invention of a Memory: Congo Square and African Music in Nineteenth-Century New Orleans', Revue française d'études américaines 98/2 (2003), 71.
} 
as it was transferred to the page. Following on from Latrobe, the primary perpetrators of our problematic understanding of Congo Square's relationship to jazz history are intellectuals George Washington Cable, Louis Moreau Gottschalk, and Lafcardio Hearn. ${ }^{45}$ Gottschalk, a composer active some 30 years before the other two, wrote the influential piece 'Bamboula' after the African drum of the same name. ${ }^{46}$ Partially thanks to the later writings of Cable and Hearn, the piece was thought to have been inspired by the strange sounds Gottschalk heard at the square. But as Widmer points out, not only was the piece written in France, only certain peculiarities in the left hand suggest the influence of percussion. ${ }^{47}$ In fact, Gottschalk only spent two years in New Orleans as a child, and thus it was more likely he was pandering to the current trend in France for exotic sounds. By the time Cable and Hearn took up the mantle of facilitating interest in the square in the late 1870s, congregating in the square had been outlawed for some 20 years.

This was not to deter Cable, who wrote the following account in 1879:

On a grassy plain under the ramparts, the performers of these hideous discords sat upon the ground and faced each other, and in their midst the dancers danced. They gyrated in couples, a few at a time, throwing their bodies into the most startling attitudes and the wildest contortions, while the whole company of black lookers-on, incited by the tones of the weird music and the violent posturing of the dancers, swayed and writhed in passionate sympathy, beating their breasts, palms, and thighs in time with the bones and drum, and at frequent intervals lifting, in that wild African unison no more to be described than forgotten, the unutterable songs of the Babouille and Counjaille dances, with their ejaculatory burdens of 'Aie! Aie! Vodou Magnan!' and 'Aie Calinda, dance Calinda! ${ }^{48}$

This exciting and evocative account would no doubt have served to foster interest in the square, but as Henry Kmen points out, Cable was here referring to events occurring long before his time, in a large part imagining the sights and sounds one might have witnessed..$^{49}$ Here then we begin to see the persistent power of cultural memory and its relationship to conceptual distance; thanks to a memory's ability to shift through liminal space, Cable 'experienced' the goings on of Congo Square vicariously. His temporal and cultural remoteness, though, meant he was invested in, and contributed to, a myth instigated by Latrobe. Yet though the likes of Cable and Hearn may have been temporally removed, they were still a lot closer than future jazz scholars. And geographically speaking, they were very close indeed. So for all the misinformation and misunderstandings perpetuated by these three intellectuals, the accounts resonated with the early historians of jazz, who subsequently saw the square as a convenient starting point for the

\footnotetext{
45 Ted Widmer 'The Invention of a Memory: Congo Square and African Music in Nineteenth-Century New Orleans', Revue française d'études américaines 98/2 (2003), 72.

46 Ibid.

47 Ibid.

48 lbid., 73.

${ }^{49}$ Henry A. Kmen, 'The Roots of Jazz and the Dance in Place Congo: A Re-Appraisal', Anuario Interamericano de Investigacion Musical 8 (1972), 6.
} 
music's development. ${ }^{50}$ Jazzmen from 1939 explicitly cited Congo Square as the primary instigator, stating "a century ago slaves met there every Saturday and Sunday night to perform the tribal and sexual dances they bought with them from the Congo". ${ }^{51}$ While the timing may have been somewhat more accurate then what was purported by Cable, Kmen points out that not only would the dances have never taken place at night, they also would never have taken place on a Saturday. ${ }^{52}$ Even Amiri Baraka, who makes the crucial observation that the discourse on New Orleans ignores the extensive migration of African Americans throughout the rural south, claimed the square "rocked nightly" to the sound of the Bamboula. ${ }^{53}$ These historical inaccuracies reveal the triviality of historical fact relative to the "invention" or myth of Congo Square for early jazz historians. Congo Sqaure, or a mythically imbued idea of it, became an important narrative device for these writers, who strategically deployed it within their histories to help tell the tale they wanted to tell. But what story were they interested in telling? And how do places such as Congo Square become mythologised? As has been explained previously, Bruce Lincoln and Christopher Small argue that 'myth' can be distinguished from 'history' through this notion of authority, evaluative rebranding of the past to serve present needs. This is to say that a mythical recitation of history doesn't serve to outline objective fact, instead such narratives become devices that point toward how things should be. Authority is thus defined through the ability to evoke emotive responses that in turn mobilise social agents under various signifiers of social identity. What is more, the invocation of myth can foster social identity that can be broadened or localised depending on the myth and the objective of those reciting them.

The fascination with Congo Square, and by extension, New Orleans more broadly, can therefore partially be explained by contested notions of jazz and how it should be understood among early historians and critics, who were writing at a time in which "the first jazz war" was being fought. ${ }^{54}$ This "war", according to Bernard Gendron, was between modernists on one side, who saw jazz as a music of progress, and New Orleans revivalists on the other, who considered the slick, "symphonic pretentions" of the swing industry as a sharp departure from the "pure" and "true" principles of jazz. ${ }^{55}$ As the name they bestowed upon the music demonstrates, the qualities they saw in jazz became entwined within a specific locality; it would not be much of a stretch to assume the utterance "New Orleans" would conjure imagery

\footnotetext{
${ }^{50}$ Ted Widmer 'The Invention of a Memory: Congo Square and African Music in Nineteenth-Century New Orleans', Revue française d'études américaines 98/2 (2003), 76.

${ }^{51}$ Henry A. Kmen, 'The Roots of Jazz and the Dance in Place Congo: A Re-Appraisal', Anuario Interamericano de Investigacion Musical 8 (1972), 5.

52 Ibid.

${ }^{53}$ Amiri Baraka, Blues People: Negro Music in White America (New York: Morrow Quill Paperbacks, 1963), 19.

${ }^{54}$ Bernard Gendron 'Moldy Figs and Modernists: Jazz at War (1942-1946)', in Jazz Among the Discourses, ed. Krin Gabbard (Durham: Duke University Press, 1995), 32.

${ }^{55} \mathrm{lbid}$.
} 
far beyond its status as a city in the southern United States. To win this war, the modernists and the "moldy figs" would need to deploy a convincing notion of how jazz should be understood, and would thus need to enhance their discursive strategies with a degree of Lincolnian authority. For the revivalists, one of the key strategies was to cast jazz as a folk music. ${ }^{56}$ As the majority of the revivalists were associated with the political left such an approach could indeed imbue their conception of the music with the necessary authority, particularly as distinctions, both aesthetic and ideological, between 'high' and 'low' culture were already familiar in critical discourse. ${ }^{57}$ But this would prove a tough sell, as Gendron suggests:

The claim that New Orleans jazz is folk music could not be maintained without trivialising the very notion of the folkloric. A particular cultural product counts as 'folk music,' in the strong sense of that expression, if it has been produced and transformed anonymously over generations, outside of any modern culture industry, by artists and craftpersons unschooled in any prevailing academy. Of these three criteria, only the latter seems to be satisfied by early jazz..$^{58}$

To counter this, some revivalists sought to amend their claim slightly by suggesting that early jazz was based on folk music, "rooted in a whole store of Negro folk music(s) from spirituals and folk songs, to hollers, street cries, play party songs, and nursery rhymes." ${ }^{59}$ It is within a claim like this that Congo Square becomes a useful discursive tool. To present jazz this way would require a relatively static and essentialised notion of 'Africa,' the mythical point of origin from where the majority of expressive characteristics that informed the abovementioned practises was thought to have originated. ${ }^{60}$ With a fixed point of origin, with all the 'timeless' and 'uncorrupted' connotations it brings with it, the next step in the construction of the narrative was a clear and tangible link to early jazz. Paul Oliver could not have put it more bluntly when he said that for the early jazz critics "the hiatus between the cessation of slavery and the commencement of jazz is accounted for by the persistence of dancing and drumming in Congo Square." ${ }^{\prime 61}$ The myth of New Orleans then, thanks in part to places like Congo Square, came to represent the 'pure' and 'authentic' vision of jazz lauded by the revivalists. As such, this neat little compartmentalised narrative, composed as it was of memories real or imagined, became the 'master narrative' once it found its way into the likes of Jazzmen and Rudi Blesh's Shining Trumpets: A History of Jazz. ${ }^{62}$ As the latter title suggests, this 'master narrative' became the 'history' of early jazz as the term

\footnotetext{
${ }^{56}$ Bernard Gendron 'Moldy Figs and Modernists: Jazz at War (1942-1946)', in Jazz Among the Discourses, ed. Krin Gabbard (Durham: Duke University Press, 1995), 39.

${ }^{57}$ lbid.

${ }^{58} \mathrm{Ibid}$.

$59 \mathrm{lbid}$.

${ }^{60}$ Paul Oliver, 'Savannah Syncopators: African Retentions and the Blues,' in Yonder Come the Blues (Cambridge: Cambridge University Press, 1970), 22.

${ }^{61}$ Ibid., 27.

62 Rudi Blesh, Shining Trumpets: A History of Jazz (New York: De Capo Press Inc.,1946), 161.
} 
is generally applied. But because both the master narrative and the objective realities of that time and place had to be funnelled through multiple liminal points on their way into the texts mentioned above, in this instance 'myth' and 'history' are virtually indistinguishable.

The story of the dawn of jazz was thus beginning to take shape, but like all good stories, it needed a main character. Enter "first man of jazz" Buddy Bolden. This is the point where the 'origin' myth as it applies to physical places meets the 'founding father' myth. According to Don Marquis, who tirelessly researched the enigmatic figure in the 1970s, Bolden was born to Wentmore and Alice Harris Bolden on the $6^{\text {th }}$ of September $1877 .{ }^{63}$ By his early 20 s Bolden had apparently developed some degree of musical acumen, as he was listed as a music teacher in the city's directory in 1901, though the only known paid engagement featuring his orchestra was for a Carnival Ball in 1903. ${ }^{64}$ It was another 3 years before the next reputable mention, this time from a local newspaper which reported that he had assaulted his motherin-law, perhaps the first in a series of accounts of varying historical rigour that reference the musician's degrading mental health. ${ }^{65}$ On April $4^{\text {th }}$ the following year he was declared legally insane and by June he was transferred to the Jackson Insane Asylum in Louisiana where he would remain until his death on the $4^{\text {th }}$ of November $1931 .^{66}$ It would be something of an understatement to suggest that the amount of robust biographical information on the man is dwarfed by the wealth of dubious anecdotes and apocrypha. As already mentioned, Congo Square was viewed by the likes of Frederick Ramsey Jr and Charles Edward Smith (co-editors of Jazzmen from 1939) as a link between New Orleans music making and that of Africa, and in turn Buddy Bolden became the link between Congo Square and jazz, with the editors going so far as to say "In New Orleans you could still hear the Bamboula on Congo Sqaure when Buddy Bolden cut his first chorus on cornet." ${ }^{97}$ Again the effectiveness, or authority, of a myth as Lincoln envisages it hinges upon its ability to evoke emotive responses. Bolden, as a sort of personified point of origin, achieved this as "the image of Bolden that was created in this search for any kind of biographical verification filled an emotional need to create a narrative about the early jazz decades around a figure larger than the little information that existed about him could actually support." 68 Jazzmen played a crucial role in exacerbating this image of Bolden though the inclusion of an epigraph featuring another, though lesser known, 'founding father' known as Bunk Johnson. ${ }^{69}$ Johnson claimed: "So you tell them

\footnotetext{
${ }^{63}$ Samuel Charters, A Trumpet Around the Corner: the Story of New Orleans Jazz (Mississippi: University of Mississippi Press, 2008), 83.

64 lbid., 84.

65 lbid., 85.

66 lbid., 86.

${ }^{67}$ Henry A. Kmen, 'The Roots of Jazz and the Dance in Place Congo: A Re-Appraisal', Anuario Interamericano de Investigacion Musical 8 (1972), 5.

${ }^{68}$ Samuel Charters, 86.

69 John Gennari, Blowin' Hot and Cool: Jazz and its Critics (Chicago: University of Chicago Press, 2006$), 124$.
} 
that Bunk and King Bolden's band was the first ones that started jazz in the city or any place else. And know you are able to go ahead with your book." 70 Of course Johnson stated this only after being questioned about Bolden on numerous occasions, and so it could be argued that in playing into the mythical authority given to Bolden he simultaneously bolstered his own image in the ensuing historical narrative. Never the less, his input "endowed Jazzmen with the status of jazz gospel among the traditionalists." 71

Here is an invaluable example in the way compounding representations of places and people are able to be harnessed and deployed to cater to values and ideologies of the present. The 'history' of early jazz was in fact deeply rooted in myth, as representations of Congo Square as the link between Africa and jazz travelled through liminal space from Latrobe's initial remembrance to Cable and so on. As has been established, however, the myth of Congo Square has come under fire from the sources referenced above. Kmen, Widmer, and others have contested the master narrative, often by providing competing narratives of their own. Unfortunately, the model I have outlined as a means of making sense of the construction of myth is still at play, regardless of whose narrative it is or the intent behind its construction. In effect, they are fighting myth with myth insofar as both narratives serve ideological purposes, and are therefore gestures toward paradigmatic truth. But given the temporal distance between them and the events in Congo Square, offering a counter-myth is one of the only real strategies available.

The miniature case study outlined above demonstrates the interrelationship between myth, history, memory, and liminality. The two former categories draw their content from the same raw materials, which are simultaneously subjected to the transformative power of liminal spaces. As the distance in time, culture and geography grew ever greater, the more these early jazz historians were invested in myth. In the next chapter I'll be looking at another way of challenging the mythical representation of places: through collapsing the physical distance between oneself and the site of cultural memory.

\footnotetext{
70 John Gennari, Blowin' Hot and Cool: Jazz and its Critics (Chicago: University of Chicago Press, 2006), 124.

${ }^{71} \mathrm{lbid}$
} 


\section{Chapter One: Harlem Jazz Past and Present}

This chapter will explore the ways in which mythologised impressions of place that exist within cultural memory can be manipulated by the conception of distance outlined in the Introduction. Based on a combination of historiographical inquiry and ethnography, I argue that if this three-fold notion of distance grows or stays the same, a relatively static representation of place persists. This persistence stems from individual memories (often from prominent exponents of jazz) concerning Harlem filtering through liminal space and finding their way into historical documents, now codified within a 'master narrative' with the capacity to reach an international audience, stretching this idea of distance even further. The strength of a myth, therefore, depends on how removed one is (whether culturally, geographically, temporally, or a combination of all three) from the initial memories that served as the building blocks of representation.

But much like the physical landscape of Harlem, representation within cultural memory is not entirely immutable. While the present chapter will explore the representation of Harlem as a hotbed of cultural expressivity, with a particular focus on jazz in the so-called Harlem Renaissance, it was not always that way. Nor, for that matter, is it necessarily the case in the present. This last point will be illustrated through my ethnographic work. By physically travelling to Harlem, I effectively caused a collapse in distance required to maintain a myth. This collapse, I will argue, destabilises the myth, causing a clash in representation and in some cases prompting active attempts to maintain it. The changing face of the Harlem of material reality is visibly marked by representations of its former glory, amounting to an investment in the most rigid of my conceptions of distance: time.

\section{Harlem in Jazz Historiography}

The mythologised Harlem that exists suspended in cultural memory thanks to various textual representations is an exciting place. Ted Gioia, writing in The History of Jazz, the first book I read on the 
subject and a core text book in many university courses on jazz, ${ }^{72}$ devotes an entire chapter to Harlem. This is telling in and of itself, insofar as it speaks to the prominence the place has in jazz discourse. In opening the chapter, he writes of "two Harlems." 73 One of these Harlems was the Harlem of material reality, a harsh reality at that for many inhabitants. ${ }^{74}$ The other Harlem, the point of pilgrimage for many of the leading African American intellectuals of the day, "symbolised a coming of age for all African Americans - whether living in the North or South, East or West - who participated vicariously, if not in fact, in the formation of a community where they could exist not as a minority culture, dependent on the tolerance or philanthropy of others, but as a self-sufficient body. ${ }^{75}$ This second Harlem is obviously of particular interest here. With this single quote, Gioia exemplifies the idea of myth as conceptualised by Lincoln: a mythically endowed representation of Harlem, removed from the often painful realities of the day, served to mobilise an otherwise disparate and dislocated group of individuals under the banner of what Alain Locke dubbed the "New Negro."76 The conceptual borders of Harlem, according to Gioia, were broken down to encapsulate the entirety of the African American community. Furthermore, in describing the second Harlem, he writes: "it is tempting to reach for scriptural imagery in describing this vision of Harlem. Here was the promised land for a downtrodden race, delivered from slavery as in the Old Testament, now answerable to its own needs, and finally free to pursue its own vision of civil society." 77 And Eric Lott, when discussing bebop, characterises Harlem as:

A magic place, a refuge that lent young musicians, triply alien - migrant, negro, occupationally suspectthe courage to conquer. Since among the major innovators only Max Roach and Thelonious Monk were from New York, Harlem offered a rediscovered community of things they had left behind - feasts, talk, home. The phrase of the moment may have been 'Harlem is nowhere,' but for the musicians it was the logical place in which to coherently combine the various regional styles they had brought with them. ${ }^{78}$

It is stirring passages such as these that helped foster my, and presumably other people's, interest in Harlem within the context of jazz. Even though, as Scott DeVeaux suggests, Harlem's position as the main centre of jazz was in decline as early as the $1940 \mathrm{~s},{ }^{79}$ the language that punctuates these passages this talk of "magic" and "scriptural imagery"- is precisely the kind of language to stimulate the emotional

\footnotetext{
72 Pedagogical considerations can also help to explain the persistence of a mythologised narrative of jazz. See, for example, Scott DeVeaux, 'Constructing the Jazz Tradition: Jazz Historiography', Black American Literature Forum 25/3 (1991).

${ }^{73}$ Ted Gioia, The History of Jazz (New York: Oxford University Press, 1997), 93.

$74 \mathrm{lbid}$.

75 Ibid.

${ }^{76}$ Paul Allan Anderson, Deep River: Music and Memory in Harlem Renaissance Thought (Durham \& London: Duke University Press, 2001), 2.

77 Ted Gioia, The History of Jazz (New York: Oxford University Press, 1997), 93.

${ }^{78}$ Eric Lott, 'Double V, Double-Time: Bebop's Politics of Style', Callaloo 36 (1988), 599.

${ }^{79}$ Scott DeVeaux, The Birth of Bebop: A Social and Musical History (California: University of California Press, 1997), 288.
} 
responses that Lincoln casts as integral to the success of a myth. It is also worth reiterating here too the title of the book the latter quote came from: The History of Jazz. The juxtaposition between this succinct, no-nonsense title and the passages referenced above reveals the complex interplay between notions of 'myth' and 'history'. Further, this particular book proved particularly influential in fostering my interest in Harlem, and jazz in general. And so it was this book that initially introduced the static representation of the borough that persisted until I finally travelled there many years later. This fixed representation can be explained by Barthes, who argues: "for this interpellant speech is at the same time a frozen speech: At the moment of reaching me, it suspends itself, turns away and assumes the look of a generality: it stiffens, it makes itself look more neutral and innocent." ${ }^{80}$ Thanks to the far-reaching powers of historical texts-asmythical-modes-of-speech, this representation, this particular cultural memory of Harlem was able to endure long after the context in which the initial remembrances stemmed from ceased to be. The implication here is that in employing such emotive language, underpinned by subjective remembrances, such 'histories' are perpetuating myth, further emphasising my central claim that, they are forever engaged in conceptual conversation.

\section{The Emergence of Harlem}

As mentioned at the beginning of the chapter, this was not the first mythical representation of Harlem that piqued the interest of outsiders. To elaborate on this last point, it is necessary to take a step back and explore the development of the area. It is worth noting at this point that in presenting the following description in the form of a narrative, as I have elected to do, I am also engaged in the myth-making process. As should hopefully be clear by now, there is no easy way past this dilemma. Nevertheless, an examination of the canonised narrative can reveal the ways cultural memory of the area can both shift and remain constant, depending on distance.

Harlem, both as a geographical locale and a site of cultural memory, has enjoyed a multitude of changes in its 350 odd year history. Andrew S. Dolkart and Gretchen Sullivan Sorin, authors of Touring Historic Harlem: Four Walks in Northern Manhattan go so far as to say: "no other neighbourhood in New York City conjures up such a diversity of images as does this section of Northern Manhattan." ${ }^{81}$ And Michael Henry Adams, writing in Harlem, Lost and Found: An Architectural and Social History 1765-1915, claims that "there are certain places where circumstances, people, and ideas meet to create a momentous

\footnotetext{
${ }^{80}$ Roland Barthes, 125.

${ }^{81}$ Andrew S. Dolkart, Gretchen Sullivan Sorin, Touring Historic Harlem: Four Walks in Northern Manhattan (New York: New York Landmarks Conservancy, 1999), 7.
} 
historic site." ${ }^{22}$ These two discursive sound-bites speak to the power places can yield in informing understandings of cultural history.

But while the mythical representation to be examined in this chapter - that of a focal point of expressive culture - is arguably the most persistent of representations attached to Harlem, it was not the first. Of course, this can partially be explained by physical changes to the space; as Harlem went from rural township to urban hotspot, these shifts in dominant representation were inevitable. That said, physical changes to a site of cultural significance can often occur faster than the shifting of myth, particularly if said myth has been cultivated and codified into a 'master narrative.' By individual memories moving through liminal space to create a mythologised cultural memory, future individuals have the potential to experience Harlem vicariously, and this can be a drawn out process. As memories of the area are conjured and then transmitted via the various modes of speech Barthes describes, it passes through at least two liminal phases. During these phases, as well as while the memory is 'stored' in a memory bank, the memory is subject to change; it can be degraded and transformed, and imbued with an ideological slant. The eventual recipient, therefore, does not obtain a memory, nor even a representation of a memory, but a series of compounded representations of a memory. Once said representation has been received, the same process operates in reverse; the representation travels through two more liminal phases, subject to the same transformative conditions.

Established by then-Governor Peter Stuyvesant in 1658, the village of what was then known as Nieuw Haarlem was a social and political hub that centred around the river at $125^{\text {th }}$ Street. ${ }^{83}$ Its persistent association with African American culture can in fact be tentatively traced all the way to the beginning of the colonial period; as the Dutch were slave-owners, there was a "substantial African population from the inception of its settlement. ${ }^{" 84}$ But this was far from the image of urban expressivity that would frame later discourse on the area. Although it was considered a part of New York City as early as 1683, it was very much a rural area until the construction of the elevated railway lines along $2^{\text {nd }}, 3^{\text {rd }}$, and $8^{\text {th }}$ Avenues in the late $19^{\text {th }}$ century. ${ }^{85}$ It was around this time that much of the farmland in the plains began to deteriorate,

\footnotetext{
82 Michael Henry Adams, Harlem, Lost and Found: An Architectural and Social History 1765-1915 (New York: Monacelli Press, 17.

${ }^{83}$ Andrew S. Dolkart, Gretchen Sullivan Sorin, Touring Historic Harlem: Four Walks in Northern Manhattan (New York: New York Landmarks Conservancy, 1999), 7.

${ }^{84}$ Ibid., 8.

${ }^{85} \mathrm{lbid}$.
} 
and yet for many New Yorkers the name still carried with it an image of pastoral tranquillity, and so was a popular spot for family outings. ${ }^{86}$

Here is perhaps the earliest example of Harlem as a site of cultural memory for city dwellers. Despite the fact that the land had lost much of its fertility, and the fact that shanty towns (comprised of Irish, German, and other immigrant groups) began to spring up around the same period, these visiting New Yorkers were still invested in a memory that had endured well beyond the span of a human lifetime. In this sense the urban New Yorker's vision of Harlem was the result of a series of compounding representations, as the initial memory shifted through liminal space from person to person, group to group, gradually becoming more mythologised. Further, like the other mythical representations explored in this thesis, these representations were far from neutral. Indeed, it is reasonable to assume that for residents in a city growing at a rapid pace thanks to immigration on a massive scale, Harlem represented a break from the hustle and bustle from urban life. This was a memory experienced through a nostalgic lens, a lens that grew ever more sullied as time went on. But as mentioned previously, to maintain such a myth requires a degree of distance between the source of the memory, and the individual agents conjuring its mythologised representation. The aforementioned elevated railway lines, as well as the New York and Harlem Railroad completed in $1837,{ }^{87}$ enabled greater ease of access to the area than ever before. This collapsing of spatial distance had the unintended consequence of allowing such travellers to experience a clash of representation; the difference between the Harlem of lived experience circa 1880, with its shanty towns and deteriorating farmland, and the idyllic, pastoral paradise of cultural memory ensured that such a myth could never survive.

With the decline in agricultural possibilities came the inevitable urbanisation of the Harlem area. The 1880s and 1890s saw intensive development, facilitated by the construction of the aforementioned rail systems around the same time. ${ }^{88}$ A key component of this development was the erection of the iconic row house design, ${ }^{89}$ an architectural style that still features prominently in the Harlem of the present day. Initially the developers sought to attract middle and upper-middle class homeowners, predominantly white protestant families, who were attracted to its "quiet ambiance, its abundant parkland, and the low cost of housing in comparison to other Manhattan neighbourhoods." ${ }^{90}$ This developmental boom also saw the establishment of civic and religious institutions, such as the multitude of Methodist and Baptist

\footnotetext{
86 Ibid., 9.

87 Ibid.

${ }^{88}$ Andrew S. Dolkart, Gretchen Sullivan Sorin, Touring Historic Harlem: Four Walks in Northern Manhattan (New York: New York Landmarks Conservancy, 1999), 10.

89 Ibid.

90 Ibid, 11.
} 
churches that punctuate the landscape. ${ }^{91}$ Further, economic prosperity combined with the relatively low cost of living attracted large numbers of immigrant communities such as Italians and Eastern European Jews, "establishing new ethnic enclaves" in the borough. ${ }^{92}$ While there was a reasonably prominent African American population, the majority still resided in the west mid-town area colloquially known as The Five Points, or more specifically, the area between Centre Street, Canal Street, Bowery Street, and Park Row. ${ }^{93}$ This was to change somewhat in 1904 , when the subway was completed. For developers in Harlem, the new ease of access to the outer reaches of New York City did not have quite the desired effect, as potential homeowners were beginning to gravitate toward areas such as the Bronx, where houses were generally cheaper and newer than their Harlem counterparts. ${ }^{94}$ This, combined with the work of a black realtor named Philip A. Payton Jr, saw Harlem landowners gradually rent their properties to African American families. ${ }^{95}$

\section{The Harlem Renaissance}

Payton Jr has been highlighted by Michael Adams as an instrumental force in establishing Harlem as what would become known as the "unofficial capital of black America." 96 With the decline in interest from ethnically white tenants, Payton Jr set about appealing to landowners to let them rent to African Americans, with the fact that they would be forced to payer higher rents as his ace in the hole. ${ }^{97}$ It was these inordinate rent prices that eventually led to Harlem 'rent parties,' in which African American residents would throw parties to help cover the basic costs of living, ${ }^{98}$ and would come to spark the interest and patronage of the likes of George Gershwin. ${ }^{99}$ According to Adams, Payton Jr's original vision

\footnotetext{
${ }^{91}$ Andrew S. Dolkart, Gretchen Sullivan Sorin, Touring Historic Harlem: Four Walks in Northern Manhattan (New York: New York Landmarks Conservancy, 1999), 11.

92 Ibid, 12.

93 Michael Henry Adams, Harlem, Lost and Found: An Architectural and Social History 1765-1915 (New York: Monacelli Press, 19.

${ }^{94}$ Andrew S. Dolkart, Gretchen Sullivan Sorin, Touring Historic Harlem: Four Walks in Northern Manhattan (New York: New York Landmarks Conservancy, 1999), 14-15.

95 Michael Henry Adams, Harlem, Lost and Found: An Architectural and Social History 1765-1915 (New York: Monacelli Press, 19.

96 lbid., 20.

97 Ibid, 19.

98 Ibid.

${ }^{99}$ Samuel Floyd Jr, Black Music in the Harlem Renaissance: A Collection of Essays (California: University of Tennessee Press, 1993), 3.
} 
of Harlem was a place in which both sides of the colour divide could live side by side. ${ }^{100}$ Unfortunately the general ethos that governed race relations in America at the time ensured that it wouldn't be the case, and thus what became known as the "white flight" out of Harlem began in earnest. ${ }^{101}$ Not long after, during the so-called Great Migration, the population of African Americans living in New York grew by a staggering $80 \%$, with the majority settling in Harlem. ${ }^{102}$ But it was not only those who hailed from the rural south making their way to the borough; during the same period, people from the further reaches of the African diaspora (particularly from Caribbean areas like the West Indies) also made the journey to this new "capital of black America." 103 But despite some common ground, relations were not always harmonious between African Americans and their Caribbean counterparts; the latter generally had better access to education in their colonial points of origin and were thus more familiar with European custom. Moreover, those from the Caribbean were more likely to be Roman Catholic or Episcopalian than Methodist or Baptist. ${ }^{104}$ It was arguably these tensions (among other things, not least of which was the repressive state of race relations in America, even in the relatively progressive North) that fostered the need to construct and articulate a sense of empowered communal identity. ${ }^{105}$ This need, in turn, can arguably be seen as a key impetus for the coming together of writers, thinkers, folklorists, and musicians in a movement dubbed the Harlem Renaissance.

As is the case with any narrative conceptualised as 'history,' marking the starting point of the Renaissance can be a fraught (yet, looking back to Hayden White and Jennifer Frost, an apparently necessary) task. Samuel Floyd illustrates this in his chapter 'Music in the Harlem Renaissance: an Overview.' Some writers suggest 1921 as the start date, the year Shuffle Along, a play by Noble Sissie and Eubie Blake, made its debut on Broadway. ${ }^{106}$ Other commentators argue it began 4 years later, when Alain Locke, a key thinker and writer of the movement, published his book The New Negro. ${ }^{107}$ Still others posit 1917 as a potential starting point, the year James Weldon Johnson published his first book of poems entitled 50 Years and Other Poems. ${ }^{108}$ Whatever date one prefers, the Harlem Renaissance was a period in which notions of cosmopolitanism and upward mobility came to the fore, and the arts were seen as an

\footnotetext{
${ }^{100}$ Michael Henry Adams, Harlem, Lost and Found: An Architectural and Social History 1765-1915 (New York: Monacelli Press, 20.

101 Ibid.

102 Ibid.

103 Ibid.

${ }^{104}$ Michael Henry Adams, Harlem, Lost and Found: An Architectural and Social History 1765-1915 (New York: Monacelli Press, 22.

105 Ibid.

${ }^{106}$ Samuel Floyd Jr, Black Music in the Harlem Renaissance: A Collection of Essays (California: University of Tennessee Press, 1993), 1.

107 Ibid.

108 Ibid.
} 
instrumental force in ushering in the "New Negro." 109 The main proponents of this ethos were a group of intellectuals dubbed "The Six," namely Charles S. Johnson, Casper Holstein, Jesse Redmond Faucet, Walter White, James Weldon Johnson, and Alain Locke. ${ }^{110}$ The latter summed up the hope of the movement in the introduction to the aforementioned 1925 book The New Negro:

The migrant masses, shifting from country-side to city, hurdle several generations of experience at a leap, but more important, the same thing happens spiritually in the life attitudes and self-expression of the Young Negro...The wash and rush of this human tide on the beach line of the northern city is to be explained primarily in terms of a new vision of opportunity, of social and economic freedom, of a spirit to seize, even in the face of an extortionate and heavy toll, a chance for the improvement of conditions. With each successive wave of it, the movement of the Negro becomes more and more a mass movement toward the larger and the more democratic chance - in the Negro's case not only from countryside to city, but from medieval America to modern. ${ }^{111}$

This passage not only outlines the core mission of the Harlem Renaissance, but also demonstrates that, for such a mission to succeed, investment in myth and myth-making would be necessary. In particular, Lincoln's conception of mythical authority is on display in the above quote. This notion of hurdling "several generations of experience at a leap," and shifting from "medieval America to modern" brings to mind the idea that myth does not just make truth claims, but claims of paradigmatic truth. This passage therefore, is more than a poetic description of the Great Migration but an emotive expression of what the migration should represent. Again returning to Lincoln, a core purpose of constructing and disseminating myth is to mobilise social groupings, to control cultural memory to facilitate a sense of community. As mentioned previously, Harlem saw a massive influx of new residents around the same time, each individual would have perhaps felt a sense of dislocation but would have undoubtedly had their own subjective experiences of the migration (or immigration) process.

As a counter-weight to this geographical and experiential disparity, proponents of the Harlem Renaissance needed a banner imbued with sentiments of upward social, political, and economic mobility, under which all who identified as African American could feel included. This was the banner of the "New Negro." Interestingly, both Alain Locke and Sterling Brown favoured the term 'Negro Renaissance' over the 'Harlem Renaissance,' ${ }^{112}$ which suggests that in looking back at the movement, historians like Ted Gioia deemed the area itself to have a certain significance in shaping the expression associated with the

\footnotetext{
109 Paul Allan Anderson, Deep River: Music and Memory in Harlem Renaissance Thought (Durham \& London: Duke University Press, 2001), 85.

${ }^{110}$ Samuel Floyd Jr, Black Music in the Harlem Renaissance: A Collection of Essays (California: University of Tennessee Press, 1993), 1.

111 Paul Allan Anderson, Deep River: Music and Memory in Harlem Renaissance Thought (Durham \& London: Duke University Press, 2001), 1.

112 Paul Allan Anderson, Deep River: Music and Memory in Harlem Renaissance Thought (Durham \& London: Duke University Press, 2001), 2.
} 
movement. It is at this point in Harlem's history where the representations inherited by the likes of Gioia and Lott were beginning to surface. Where once is was it was collectively remembered as a place of pastoral tranquillity, it was now beginning to be remembered as an urban hotbed of empowered cultural expression. Langston Hughes, a Harlem-based poet and member of the Renaissance elite, cast Harlem as "Jazzonia" in The Weary Blues from 1926. ${ }^{113}$ It is described as:

A new world of escape and release, an exciting never never land in which 'sleek black boys' blew their hearts out on silver trumpets in a 'whirling cabaret.' It was a place where the bold eyes of white girls called to black men, and 'dark brown girls' where found in 'blond men's arms.' It was a city where 'shameless gals' strutted and wiggled, and the 'night dark girl of the swaying hips' danced beneath a papier-mache jungle moon. The most important inhabitants of this magic city are a 'Nude Young Dancer,' 'Midnight Nan at Leroy's,' a 'Young Singer' of chansons vulgaires, and a 'Black Dancer in the Little Savoy.' 114

Jazz then is the cultural lens which with Hughes viewed Harlem. It is a frenetic, heady space of hedonistic escapism, where "the rhythm of life/is a jazz rhythm." 115 He goes on to characterise it as a place of perpetual night time, where daylight illuminates the weary sadness that lays dormant just below the surface. ${ }^{116}$ Here then is a prime example of myth-making from within the confines of Harlem. Hughes offered an emotive representation of Harlem, a representation all the more potent considering his proximity both physically and temporally. This would compound upon other representations that would eventually travel through cultural, temporal, and physical space, funnelling through the likes of Gioia and Lott and ultimately through myself and beyond.

That said, some jazz musicians making the journey northward saw Chicago as a preferable space to ply their trade. ${ }^{117}$ As Burton Peretti explains: “Among all the northern black locales, Chicago's neighbourhoods and nightclubs would be the most fondly remembered by musicians. One such jazz musician, Alberta Hunter believed that 'these nightclubs in New York haven't got a chance (compared) with what the Dreamland (in Chicago) was. Only the Cotton Club...no, it didn't compare with the Dreamland." "118 Even so, Peretti goes on to say that "New York's Harlem was the largest and most celebrated destination for African American migrants. Although Harlem's job market for musicians was similar to Chicago's, its role as the black cultural capital especially attracted musicians." ${ }^{119}$ This is suggestive of both the power and vulnerability of myth as constructed by cultural memory. Alberta Hunter, who had mixed feelings at best about the Harlem scene, used to live on $139^{\text {th }}$ street, "near

\footnotetext{
${ }^{113}$ Arthur P. Davis, 'The Harlem of Langston Hughes' Poetry', Phylon (1940-1946) 13/4 (1952), 277.

114 Ibid.

115 Ibid

${ }^{116}$ Arthur P. Davis, 'The Harlem of Langston Hughes' Poetry', Phylon (1940-1946) 13/4 (1952), 277.

${ }^{117}$ Burton W. Peretti, The Creation of Jazz: Music Race and Culture in Urban America (Chicago: University of Illinois Press, 1992), 49.

118 Ibid.

119 Ibid.,47.
} 
Striver's Row and amidst the black elite on Sugar Hill." ${ }^{120}$ Hunter could have thus experienced a collapse in conceptual distance required to ensure the continuation of a given myth. Her lived experience of Harlem in the present clashed with the representations that brought her there, causing her to become disenchanted. And yet these representations were strong enough to lure musicians like herself to the borough, more so than any other northern centre. But myth-making, the constructing and deployment of cultural memory, is first and foremost built on the subjective memories of individuals, which then travel through liminal space. Even so, in constructing myth, one must be selective in deciding which individual memories to include, and which to forget, or (un)remember. The following quote from the pioneering blues composer W.C Handy provides an example of an individual, but influential, remembrance of Harlem:

In 1918 I headed for Harlem. And what a Harlem it was! Big old good-looking, easy-going, proud-walking Harlem. I strolled through the principle streets of Harlem and on $135^{\text {th }}$ street, near the old Lincoln theatre, I saw a sign on the door. It read: 'Harlem Musicians Association.' I paused to listen to a saxophone sextet and walked in, wondering whom I would meet and if anyone would know me. I was instantly recognised and, instead of a group of mediocre musicians, met the cream of New York's leaders at that time. Will Vodery, arranger of numerous Ziegfeld musical scores, invited me as his guest to the Cocoanut Grove on the Century Roof. And on the following night I was the guest of Ford Dabney at the Ziegfeld Roof. ${ }^{121}$

Five years later, Duke Ellington made the same journey. He recalled that "New York is a dream of a song, a feeling of aliveness, a rush and flow of vitality that pulses like a giant heartbeat of humanity. The whole world revolves around New York, especially my world." ${ }^{122}$ Here Ellington used similar emotive and poetic language to describe New York as Locke used to describe the great migration. Ellington was thus offering an ideologically imbued representation, a heady contribution to the cultural memory of New York. And while he doesn't mention Harlem specifically, Lincoln makes the point that a given myth can be expanded or localised to suit circumstance. Thus myths surrounding Harlem can by extension encapsulate the entirety of New York. Or, as was the case with Locke, the entire northern region of the United States. Crucially, both Handy and Ellington made these statements in retrospect; these were memories that had degraded over time, were computed into spoken language and subsequently immortalised in print, emphasising the fact that these remembrances are representations. Furthermore, remembrances such as these arguably carried more weight than that of Alberta Hunter, which introduces the 'founding father' notion (considering the highly gendered dimension of the phrase, it is sadly yet another example of the marginalisation of woman's voices in jazz discourse more generally). Simply put,

\footnotetext{
120 Ibid.

${ }^{121}$ Samuel Floyd Jr, Black Music in the Harlem Renaissance: A Collection of Essays (California: University of Tennessee Press, 1993), 2.

122 Burton W. Peretti, The Creation of Jazz: Music Race and Culture in Urban America (Chicago: University of Illinois Press, 1992), 47.
} 
the memories of 'founding fathers,' though equally as subjective and subject to degradation as any other memory, were viewed less critically than others. As memories such as these - as well as the literary representations offered by the likes of Langston Hughes, themselves built on memories of lived experience - found their way into the discourse and thus became ever more mythologised, they would have great impact on future understandings of the area, including my own.

\section{Harlem in the Present: When Representations Collide}

This section will introduce my ethnographic material. The central aim here is to further emphasise how a collapsing of distance can destabilise mythical representations of place. This destabilisation led, in my case at least, to me becoming jaded to what was once fascinating. Just how invested I was in myth became all too apparent early on in my stay. As a white, middle-class student of African American music from New Zealand in 2015, I am about as removed on all fronts (temporally, geographically, culturally) as it gets. And yet, like so many other people for a variety of reasons, I was enamoured with New York for a long time. The more I learned about jazz in New York, the more I became enthralled by an idea of Harlem. A Harlem punctuated by thriving nightclubs, by the notion that many of the most well-known exponents of the music could be heard on a bandstand on any given night. In short, I was invested in a static impression of Harlem. A Harlem immortalised by the like of Hughes, Handy, and Ellington. Although naturally I knew it would likely be vastly different when I arrived, the extent of my naivety would only become apparent once field work got underway. To demonstrate this, the following is a description of an interview with Harlem based saxophonist Peter Brown. It is important to note here that I elected to conduct one interview for each chapter, a decision largely influenced by the short time frame in which I was working. Included will be an account of my journey, with only minor edits, to meet him at Lincoln Centre, written (although in the present tense) immediately after the conclusion of the interview. It's a bitterly cold Friday afternoon in New York City, my first Friday since arriving a few days beforehand. I'm scheduled to meet Peter Brown, a Harlem-based saxophonist who agreed to an interview, at 2 oclock at the Lincoln Centre in the Southern edges of Harlem. I decide to leave my apartment in Brooklyn at roughly quarter to one, thinking it ample time to get there. It seems I've temporally forgotten I've only been here a few days, and the city is still an incomprehensible labyrinth to me. The first snag occurs as I go to enter the subway station at Smith Street and Burgan. As I have done multiple times by now, I go in on the wrong side of the road, completely confused as to which trains go to 
Manhattan, and which go to Queens. After realising my mistake and resigning myself to the fact that I had wasted yet another train fare, I cross the road and wait for the F train.

It arrives soon after, and so I sit and try to figure out which stop to get off, hoping I won't need to transfer. The train is about half full, my fellow passengers almost universally donning headphones and staring at their phones or reading a book. Unlike my first time on the F train, there's no dance crew on board to stem the boredom. At around about $35^{\text {th }}$ street the train stops and doesn't start again (my ever increasing sense of panic means I don't take note of exactly where I am). After a number of painful minutes, a crackly voice emanates through the intercom informing us that a passenger is sick on another carriage which was going to cause delays. At this point it's about 20 minutes to 2 and my sense of panic begins to border on a fully-fledged freak out. I run up the stairs to try and hail a cab which, as it turns out, it not as easy as it is in the movies. After 5 minutes of trying unsuccessfully to out-hail other people I run back downstairs, buy yet another train fare only to find the F train pulling out of the station. At this point I almost laugh out loud at the absurdity of my misfortune but instead I once again run up the stairs to try for a cab. I finally get one and once inside text Peter to let him know I might be "a little bit late." It's only now that I have time to check that I realise the Lincoln Centre is miles away from where I am. "It's ok, I'm in a cab now, it shouldn't take long," I think to myself. Wrong. With bumper-to-bumper traffic almost the entire way, I finally arrive at Lincoln Centre 45 minutes late and about 40 dollars lighter in the pocket.

Peter is sitting by the window, dressed in a jacket, sweater, and collared shirt. Thankfully he doesn't seem too phased by my lateness, so after ordering a coffee I sit down to finally get things underway. As he reads through my information sheet, however, his cheerful demeanour begins to evaporate. Upon finishing, he pauses for a moment and says: "Frankly, I find this offensive." At this point I'm so frazzled by the journey my brain is having difficulty thinking through exactly what he means by this. After stumbling over myself trying to both apologise and explain myself I realise his main concern is with my use of the word 'myth.' Eventually after a bit of back and forth we both relax a bit and conclude that his taking offence, like my journey planning, stems more from my naivety than anything else. Finally, I hit the record button on my phone and my first interview gets underway.

Me: Ok so first of all are you a local? Are you from New York?

Peter: I was born in South Florida, my dad brought the family to New York when I was 7 years old Me: Ok cool so um, how long have you been sort of, making music or involved in music making? Peter: Um..as in as an actual musician? 
Me: Well just in general I suppose

Peter: Um well it's been a lifelong thing. My mother gave me, well sent me to piano lessons, um my earliest memory I played the trombone in grade school. But I really got into jazz as something I was really interested in doing..ok as an actual player of the music, about three years ago.

Me: Ok awesome. Do you play..where abouts do you play in the New York area?

Peter: In Harlem.

Me: In Harlem. And does that, does that have any impact on how you approach playing the kind of..is there an awareness of the historic gravitas a place like Harlem has? Does that impact upon your process?

Peter: Um that's an oversimplification, of the way music in general, you know... if you want to be a classical musician Harlem might not be the place to go um to learn to play that genre of music. I happen to live in Harlem so um..if I lived somewhere else in the city, if I wanted to play jazz I would, you know, need to, I wouldn't say need to, I'd be best suited to need to go to Harlem in order to play that type of music. Because that's where it's received, and appreciated at the greatest extent.

Me: Ok um so what other areas around New York, are there other areas or is it mainly just Harlem? I know historically there was $52^{\text {nd }}$ street..

Peter: Well that, you know, was more than 50 years ago.

Me: (Laughs) yeah yeah

Peter: You know, the main places to play jazz in terms of elite professionals are in Greenwich Village. You're talking about the Village Vanguard, you're talking about Blue Note, you're talking about Smalls, you're talking about places, um, even Fatcats to a certain extent. Um and you know those types of cafes but you know the Blue Note urgh if you're.. ha..this is very difficult to talk about. Um.. I'm not sure the most knowledgeable people um who consume jazz go to the Blue Note to see it. I might not be right about that. I might not be right about that at all. Um the people who I know love jazz don't go to the Blue Note on a regular basis. They'll go to the Blue Note if there's someone in particular that they want to see play. The next time I'm going to the Blue Note is in March to see James Carter, I don't normally go to the Blue Note.

Peter, as someone who recently elected to devote himself to jazz on a full-time basis, suggests that although the pinnacle of the Harlem scene had diminished well before either of us were born, the myth of Harlem as a Mecca for jazz performance continues to persist, even for someone whose proximity is closer 
than my own. While he acknowledges that the majority of professional jazz performance occurs in Greenwich Village (suggesting the myth is indeed fragile), there was a discernible trace of disdain in his voice, particularly when discussing the Blue Note. Harlem for Peter, even in 2015, is still the ideal location, not simply for pragmatic reasons (i.e the fact that he lives there), but also because of the lingering idea that that's where those who are truly 'in the know' go to hear jazz. The next section will look at my own experiences in Harlem, with the overarching aim to explore the clash in representation between lived experience in the present and the mythologised site of cultural memory.

I'm walking to the old Cotton Club via Saint Nick Ave, I pass a yoga studio, and the Harlem School of the Arts featuring a large picture of an African American saxophone player and a young girl singing. This suggests an institutionalised attempt to tap into the cultural history of the area. As I arrive at $142^{\text {nd }}$ Street I walk past a trendy café with a wooden façade called Manhattanville, a line of Macbooks along the window. The brick buildings conform to my inherited impressions of the projects but they're surrounded by well-kept playgrounds and clean, albeit snowy streets. The locations, on $142^{\text {nd }}$ and Lennox, bears no discernible trace that the club was once here. On one side of the street is a printing store, a corner store, a pizza shop, and an organisation called West Harlem Group. On the other is a Sandwich shop. Further down Lennox is a very new looking Harlem Hospital with an impressive glass façade featuring scenes of African Americans engaged in music making and dancing, science, and what appears to be rural imports to New York during the Great Migration.

This passage, describing my journey to where the Cotton Club once resided, touches on two key issues. The first is the unexpected changes to the physical space, particularly the café, which would not have looked out of place in my home city of Wellington. Such an unmistakable clue of gentrification reflects the increase in the price of living in Harlem over recent years, ${ }^{123}$ but my surprise at seeing it also reveals the extent to which I had been invested in a relatively static representation of Harlem which, like the pastoral Harlem of old, persisted within cultural memory long after the initial temporal context that informed that memory had come and gone. But this passage also reveals the ways in which the myth of Harlem can be maintained in the wake of gentrifying forces. Visibly marking the space with imagery associated with the mythical past, à la Harlem Hospital, is arguably one such strategy. Investing in the ultimately unknowable past is a productive means of counteracting the model I have proposed as it is the one conception of distance that cannot collapse. This process was also on display at Bill's Place, an apartment in Harlem that has been repurposed as a jazz club. The following is an account of my travelling

${ }^{123}$ Areavibes.com, http://www.areavibes.com/new+york-ny/harlem/cost-of-living/. Accessed 7/02/2016. 
to and from there, and the revelations that journey revealed regarding mythical representations of place and its relationship to physical distance.

I arrive at $148 \mathrm{~W} 133^{\text {rd }}$ Street, Harlem (Bill's Place) on a snowy Saturday night. The building is literally an apartment, the only indicators from the outside is a small red sign and a plaque which states Billy Holiday was discovered here. The bandstand is set up in what would be the lounge. I arrived a bit late so I have to watch through a pass between the 'lounge' and the next room. Despite this, certain club conventions are still at play. As I struggle to find a seat, the loudspeakers are blasting bebop, presumably a precursor of what's to come. Around the two main rooms are old gig posters (Randy Weston, Mingus, and Miles Davis) and photos depicting various jazz luminaries such as Charlie Parker, Dizzy Gillespie, Count Basie, Billy Holiday, Coleman Hawkins, Lester Young, and Sarah Vaughn. There are also a bunch of pictures showing artistic depictions of jazz bands.

Parker seems a particularly strong presence here, to my right there's a collage of pictures of him, along with a short description lauding his genius. The place lets you bring your own alcohol so I pull out what I thought was a Heineken but was in fact a Coors light, to my dismay I find out that the entire box is the same, purchased in a hurry on route to the venue. I groan audibly, but never-the-less crack one and take a sip of the decidedly average beer. My beverage troubles were to prove the least of my troubles as the band takes to the stage. New York based saxophonist Patience Higgins, the band leader, tells the crowd of 20 or so that the owner of the club, Bill Saxton, will not be performing as he was recovering from surgery. It is at this moment, while sipping on my watery beer, that I begin rueing my decision to come on my last Saturday in NYC. As the club is only open Friday and Saturday nights, this was my last chance to meet him. While cursing myself for not electing to come the previous weekend, I reflect that the situation is consistent with an overriding theme that 3 weeks was not nearly enough time to do what I wanted to do; setbacks like this one are all more damaging when on such a tight schedule. The icing on the cake, however, would come later in the band's set. In the lead up to the fourth tune, just after a decent version of Ellington's 'In a Sentimental Mood,' Higgins asked who was on a Valentines date. Literally everyone else in the club raised their hand but me. The band then launches into a stirring rendition of 'My Funny Valentine.'

After watching Patience Higgins play at Bill's Place on $133^{\text {rd }}$ Street I make my way to the subway station back to Brooklyn. Its 10:30 pm, the latest I've been out by myself in Harlem. I'm walking down Frederick Douglass Boulevard, unsure of where the nearest subway station is. It's Valentine's Day, which could account for the lack of people on the street. Most of them are in their 50s and 60s. Though there are some indicators of an impoverished area (cramped corner stores, fast food, takeout places inappropriately named "restaurants") I saw no signs of danger at all. Once in the subway, I realise I've been so busy 
thinking about the gig and how to get home that I'd largely forgotten to feel weary. The feeling is near identical to the feeling I'd get if I'd been to a particularly good gig in the Hutt and was looking for a bus stop. Perhaps it's because by this point I've been to Harlem multiple times, so the "wow I'm in Harlem" factor had diminished. This suggests that my impression of the place was changing after it began to shift from vicarious experience to personal experience. I had the same feeling on the A train. The first time I was merrily singing the tune in my head as the train pulled out of the station. But it takes about 45 minutes to get from Brooklyn to Harlem so by the second time taking the A train it felt like yet another long train ride. How quickly I became jaded brings into focus what happens when ideologically imbued representations (particularly those depicting a relatively static moment in time) clash with personal experience. Institutions like Bill's Place seem to perpetuate these mythical representations, manipulating cultural memory to a time gone by, thereby situating themselves in the narrative they are constructing.

Bill's Place is clearly invested in maintaining the myth of Harlem's musical past. While my theorising on this point is hindered by the fact I never got the chance to speak to him personally, the plaque outside and the imagery inside reveal a process similar to that of Harlem Hospital. Ultimately, what stood out to me about that particular gig is just how quickly the strength of a particular mythical representation can diminish. Robert Archibald writes:

Place is the crucible of memory. As Friedlander discovered and then recorded in his book, you can 'view everything with indifference' and then stifle every sort of reverence - until you go back to where it happened. Then the most carefully erected barriers crash. The places where things happen are stimuli to memory, and there in those places, memories will pour out with irresistible force. An individual will feel this sometimes overwhelming power in a place, and so will a family, even a community or a nation. ${ }^{124}$

Archibald is generally referring to events that the individual directly experienced, but places can also facilitate a similar sensation when those events are experienced vicariously via cultural memory. In my time in New York I certainly felt the "overwhelming power" places like Harlem can conjure, but I would add that this sensation is short lived. In my early visits to Harlem, even the most innocuous details carried with them a special significance - the first time I took the A train, for example. But startlingly quickly, the more trivial and mundane issues in life forced their way back to the fore. Suddenly things such as finding the station and wondering how much money I had left became more important that what particular train I was catching. Closing the distance, in this case physically, between myself and the site of cultural memory brought to mind how powerful and yet fragile mythical representation is simultaneously; my uncomfortable experience with Peter and my surprise at seeing trendy cafes revealed just how distant I was from the remembrances of prominent Harlemites that informed my inherited memory of Harlem,

\footnotetext{
${ }^{124}$ Robert Archibald, 'A Personal History of Memory', Social Memory and History: Anthropological Perspectives, ed. Maria G. Cattel, Jacob J. Climo (California: Altamira Press, 2002), 68.
} 
while the sheer speed at which I became jaded to my surroundings suggest that myth remains vulnerable to increases in proximity.

\section{Conclusion}

In summation, Harlem as the focal point of jazz is a myth that has endured long after its tenure of prominence in the 1920s. This persistence is achieved through the theoretical model I have outlined thus far: the individual remembrances of the likes of Langston Hughes, W.C Handy, and Duke Ellington, themselves recalled in retrospect, travelled through multiple liminal points until they entered the pages of the history books, and ultimately, to me. Their individual memories, in other words, manipulated the ensuing cultural memory, which in turn led to my inheritance of a static representation. Despite what the book titles might suggest, any 'history' of jazz in Harlem is not only dependent on myth for raw materials, but actively contributes to it through the adoption of emotive language. Further, it is in this notion of distance that allows for such myths to persist.

And yet, through collapsing said distance also reveals the fragility of myth. Much like the tourists of old who expected pastoral paradise but were confronted by a rural slum, my travels there shed light on the gulf between the mythical past and lived experience in the present. It is this dilemma which arguably triggered an active attempt to enrich the physical space with visual markers of times gone by in the wake of gentrifying forces. 


\section{Chapter Two: The Bronx and the Origins of Hip Hop}

In the previous chapter I outlined the ways in which representations of places are negotiated via distance, the core argument being that the closer one is to the site of cultural memory, the more fragile the cultural memory, or myth, becomes. The question for us here then is how, if the liminal space in which memory travels through yields transformative power, has the story of the Bronx-as-point-of-origin endured the way it has? A potential answer lies in this notion of the 'founding fathers.' Much like Bills Place in Harlem, certain actors can attempt to control cultural memory, a control exercised by near constant reiterations, counteracting the uncertain and malleable nature of memory. In other words, certain narrated remembrances, certain anecdotes, are repeated so often they come to form the 'master narrative.' The power of founding fathers to control cultural memory is thus dependent on their own mythologised status; their memories are not met with the same degree of criticism as those of others. Combine this process with distance, broadly conceived, and the myth retains its potency.

But the Bronx myth - strong as it is - has not entirely escaped scrutiny. A documentary entitled Founding Fathers: The Untold Story of Hip Hop, the inspiration for my usage of the phrase, seeks to problematize the story as we receive it. Several artists, such as King Charles and the Disco Twins challenge the primacy of the Bronx as the breeding ground for what we now call hip hop. Their musical practises, they claim, had a lot in common with the canonised Bronx artists like Kool Herc, Afrika Bambaataa, and Grandmaster Flash, but their efforts have either been largely ignored or categorised as disco. Thus, the myth of the Bronx, like all myths, is grounded in claims of paradigmatic truth; in this case claims of what hip hop is, or perhaps, what it should be. The first section of the following chapter will present the Bronx as a mythologised site of cultural memory, exploring the origin myth as it stands today while situating it within an environmental context that arguably enriched the now familiar narrative. The section will focus on borders, an important construct when considering the origins of hip hop. As will become clear, the founding fathers are able to offset the nature of memory chiefly through the invocation of borders, both geographically and in terms of genre. The marginalised artists mentioned above, I will argue, sit within a grey area as far as the latter is concerned, demonstrating that such borders are in flux and subject to contestation. I will then offer my ethnographic experiences, including my participation on the 'Hip Hop Origins Tour,' and an interview with Grandmaster Caz of the Cold Crush Brothers, himself a 'founding father' of the hip hop movement. 


\section{The Bronx is Burning}

The narrative of hip hop emerging out of the south Bronx in the early to mid-1970s is perhaps one of the more tenacious that circulate in music history. Many scholars, journalists, and artists tend to frame the Bronx as the singular point of origin in the now global phenomenon. Although the origin of hip hop is a story enshrined in myth, the supposed starting point is remarkably specific, in terms of both time and geography. The following section will re-present said narrative. Taken from a variety of sources, the overall goal with this is not to merely regurgitate a familiar story, but highlight the remarkable consistency in identifying the particular point of origin. This brings to mind Frost and White's discussions on chronological narratives. Any discreet beginning, therefore, implies an investment in myth.

In January of 1973, the New York Times began to catch wind of the rampant suffering and disenfranchisement plaguing residents of the South Bronx, the specifics of which will be explored in more detail below. Headlines like "South Bronx: A Jungle Stalked by Fear, Seized by Rage" began circulating, offering gloomy representations of a neighbourhood on the brink of collapse. ${ }^{125}$ Dr Harold Wise, a prominent doctor in Bathgate, went so far as to suggest to New York Times reporters that the South Bronx was a "necropolis, a city of death." ${ }^{126}$ It was out of this context that in the "summer of 1973, hip hop was born, and it was born in the Bronx." 127 This statement offered by Mark Katz refers to a party thrown on August 11 at 1520 Sedgwick Avenue by Jamaican transplant and high school student, Cindy Campbell. ${ }^{128}$ The story goes that she wanted raise money for some new clothes as the beginning of school was just around the corner. By borrowing a sizable sound system from her father and acquiring the hottest funk, soul, and rock records around, Cindy Campbell inadvertently earned herself a place in hip hop history. The key moment came when she enlisted her older brother, Clive, to act as the DJ. ${ }^{129}$ Clive Campbell, later immortalised as Kool Herc, had been exploring the city's dance scene since the late $60 \mathrm{~s},{ }^{130}$ and claimed to have developed a "dancefloor perspective" in his approach to DJing after watching the supposedly aloof style of the city's disco DJs. ${ }^{131}$ In those formative years before his sister's party, Herc had been amassing records both rare and popular, a blend that proved crucial in his musical development. But on that fateful summer's night on August 11, 1973, it was what he did with the records, as well as the records themselves, that "became the blueprint for hip hop." 132 In Herc's words:

\footnotetext{
${ }^{125}$ Mark Katz, Groove Music: the Art and Culture of the Hip Hop DJ (New York: Oxford University Press, 2012), 17.

${ }^{126}$ Ibid.

127 Ibid.

128 Ibid.

$129 \mathrm{lbid}$

${ }^{130}$ Alex Ogg, David Upshal, The Hip Hop Years: A History of Rap, (London: Macmillan Publishers Ltd, 1999), 13.

131 Ibid.

132 Ibid, 15.
} 
I was using some of the breakdown parts. Every Jamaican record has a dub side to it, so I just tried to apply that...One night, I was waiting for the record to play out. Maybe they're (the dancers) waiting for this particular break. I could have a couple more records got the same break in it - I wonder, how would it be if I put them all together and I told them: 'I'm going to try something new tonight. I'm going to call it a merrygo-round.' The B-boys, as I call it, the energetic person, they're waiting just to release this energy when this break comes in. ${ }^{133}$

And so with the supposed invention of the merry-go-round, the moment Herc mixed the break section of James Brown's 'Give It Up Or Turn It Loose' into the same section of 'Bongo Rock' by Michael Viner, ${ }^{134}$ a new, discrete genre was said to have been born. I phrase it as "said to have been born" because of course the importance of that night would have only been retrospectively realised; this neat little narrative of the disillusioned maverick character experiencing a spark of divine inspiration is a valuable discursive tool in tracing the now global phenomenon back to a discernible starting point. It is these 'pivot points' within narratives that are among the more fruitful to subject to the myth making process. Starting from Herc's individual memory, this retelling of the isolation of the breakbeat travelled through multiple liminal points, eventually becoming immortalised in hip hop mythology. Alex Ogg and David Upshal claim "the day Herc discovered the breakbeat was the day hip hop was born." ${ }^{135}$ Mark Katz agrees, suggesting that early hip hop is "all about the break. If you hope to understand the art of the hip hop DJ - and even the origins of hip hop - you must understand the break." 136 Thus, by mythologizing the performative pivot point, the myriad complexities that go in to the formation of any expressive culture give way to a singular, easy-to-digest moment as the representations compound. This same process then allows Kool Herc, the apartments at 1520 Sedgwick Avenue, and finally the South Bronx more broadly primacy of place in the cultural memory of hip hop.

I would also argue, however, that a key reason why the Bronx-as-Origin myth is so persistent is not just due to the fact that Kool Herc "discovered" the breakbeat there, but also the environmental factors that afflicted the space. As an avid hip hop fan for most of my life, the idea that it emerged out of an area of violence and deprivation was one of the salient facts that informed my listening. In retrospect, I cannot recall where or when I first encountered this, at this point it feels as though I've always known it. There are some interesting points to be made of this. Firstly, it emphasises the idea that memories erode over time. Secondly, and perhaps more importantly, it speaks to my contention that while individual memories provide the building blocks for cultural memory, cultural memory in turn impacts upon individual memory. There was, at least according to hip hop historian Jeffery Chang, certain circumstances that

\footnotetext{
${ }^{133}$ Alex Ogg, David Upshal, The Hip Hop Years: A History of Rap, (London: Macmillan Publishers Ltd, 1999$), 15$.

134 Mark Katz, Groove Music: the Art and Culture of the Hip Hop DJ (New York: Oxford University Press, 2012$), 17$.

135 Alex Ogg, David Upshal, The Hip Hop Years: A History of Rap, (London: Macmillan Publishers Ltd, 1999$), 29$.

${ }^{136}$ Mark Katz, Groove Music: the Art and Culture of the Hip Hop DJ (New York: Oxford University Press, 2012$), 14$.
} 
arguably helped give rise to the formation of hip hop culture. Chief among them was the construction of the Cross-Bronx Expressway, which began in $1953 .{ }^{137}$ Chang writes:

In 1953, the future of the Bronx could be seen along the seven mile man-made trench cutting through it. Once an unbroken continuum of cohesive, diverse communities, the trench was now clearing for the CrossBronx Expressway, a modernist catastrophe of epic proportions. ${ }^{138}$

That it was a catastrophe for inhabitants of the Bronx is hard to question. According to Chang, some 60,000 residents, many of them Jewish, Italian, and Irish families, had to be relocated to make way for the Expressway. ${ }^{139}$ But it is also interesting to note the manner in which he describes the Bronx prior to construction; he talks of "cohesive, diverse communities" living in an "unbroken continuum." This somewhat romantic representation of the Bronx prior to the Expressway brings to mind the way Harlem was talked about prior to urbanising forces; the idyllic pastoral paradise that gradually became something of a slum. This reinforces the idea that cultural memory, like individual memory, can shift and is subject to degradation and distortion over time. While representations of the Bronx of the 60s and 70s are heavily mythologised in the context of the narrative of hip hop history, the decades prior to that are even more steeped in myth, as the distance grows ever greater. The Expressway can thus be seen as a conceptual, as well as material, linking structure. It serves as a useful discursive tool in separating representations of the Bronx into a space of crime-ridden, urban decay that supposedly brought about the hip hop generation, and the "cohesive, diverse" Bronx almost out of reach of cultural memory. What we have here, therefore, is another mythologised pivot point, similar to Herc's invention of the merry-go-round. As will be demonstrated in section two, invoking these pivot points, these conceptual borders, is a key strategy in combatting the uncertain and interpretive qualities of compounding remembrances. The Cross-Bronx Expressway is used as a means of compartmentalising the historical narrative, arguing that the idealised communities he alludes to were irreversibly destroyed by those events. Informed by the personal remembrances of the founding fathers, the heavyweights of the myth making process, other contributors can also attempt to exercise control over cultural memory through discursive methods such as these; offering mythologised representations of the past to cater to ideological sentiments in the present.

This is not to belittle the hardships faced by those effected by the expressway but it is interesting to note that this practise of neat compartmentalisation tends to occur again and again in the construction of historical narrative. What is also interesting to note is, like Harlem, the Bronx experienced its own 'white

\footnotetext{
137 Jeff Chang, Can't Stop Won't Stop: the History of the Hip Hop Generation (New York: St. Martins Press, 2005), 10.

138 Ibid.

139 Ibid.,11.
} 
flight' as a result of the Expressway. ${ }^{140}$ By the end of the 1950s, half the white population had left the Bronx for the suburbs in Queens, Long Island, and New Jersey. ${ }^{141}$ But irrespective of the various ethnic groups that left or stayed, the aftermath of construction had some very real effects on residents of the Bronx. Although I have characterised the Expressway as a sort of mythical dividing line, this is not to say that the narrative that surrounds it is patently untrue, but rather I seek to draw attention to the cultural work it achieves in segmenting both the place of the lived reality and the story that gets retrospectively attached to it. According to Chang:

Here was the new math: the South Bronx had lost 600,000 manufacturing jobs; 40 percent of the sector had disappeared. By the mid-seventies, average per capita income dropped to $\$ 2430$, just half the New York City average and 40 percent of the nationwide average. The official youth unemployment rate hit 60 percent. Youth advocates said that in some neighbourhoods the true number was closer to 80 percent. If blues culture had developed under the conditions of oppressive, forced labour, hip hop culture would arise out of the conditions of no work. ${ }^{142}$

Despite the somewhat contentious statement about the development of blues culture, these statistics make for sad reading. Unfortunately, the situation in the South Bronx was about to get worse. So-called slumlords eventually realised they could make a tidy profit, up to $\$ 150,000$, if the dilapidated buildings they owned were conveniently destroyed by fire. ${ }^{143}$ As more and more apartment buildings became vacant, there was less of an incentive to keep the buildings maintained and so these slumlords would hire "rent-a-thugs" to do the deed for a paltry sum of $\$ 50$, while thieves plundered the charred remains for anything they could sell. ${ }^{144}$ But this insidious practice was not confined to the ghetto, rather it was entwined within the upper echelons of New York politics. Not only did insurance companies profit from the number of policies they sold to slumlords, but Daniel Patrick Moynihan, then the Democratic senator of New York, apparently stated “People in the South Bronx don't want housing or they wouldn't burn it down." 145 In a memo to President Nixon, he argued that perhaps "the time may have come when the issue of race could benefit from a period of 'benign neglect." This apparently fell on sympathetic ears. In 1968, seven fire companies were removed from the Bronx. ${ }^{146}$ In the wake of this decision, 43,000 housing units were put to the torch. As Chang puts it, "these were not the fires of purifying rage that had ignited Watts or a half dozen other cities after the assassination of Martin Luther King Jr. These were the fires of

\footnotetext{
140 Jeff Chang, Can't Stop Won't Stop: the History of the Hip Hop Generation (New York: St. Martins Press, 2005), 10.

${ }^{141}$ Ibid.

142 lbid, 13.

143 Ibid.

144 Ibid.

145 Ibid, 14.

146 Ibid.
} 
abandonment." ${ }^{147}$ If the construction of the Expressway initiated the shift in representation, it was these devastating series of events that further manipulated, and in some respects solidified, the topology of the 'South Bronx.' A New York Times article from 2013 investigated how, despite parts of the area boasting green lawns and major department stores, the South Bronx continues to be plagued by images of crime, poverty, and urban decay. ${ }^{148}$ The Bronx of the present has not yet rid itself of such unfortunate images. It continues, in other words, to be beleaguered by a nefarious mode of "frozen speech". ${ }^{149}$ These representations of the havoc wrought in the 1960s and 1970s would have initially moved from person to person, eventually reaching the memory banks of Tom Wolfe, author of The Bonfire of the Vanities as well as Daniel Petrie, who directed the cop film Fort Apache, the Bronx. ${ }^{150}$ These artistic representations were more far-reaching than through oral transferral, and therefore allowed people who grew ever more geographically, culturally, and temporally distant to 'experience' this memory of the Bronx vicariously. In Chang's words:

Here was the reconstructed South - the South Bronx, a spectacular set of ruins, a mythical wasteland, an infectious disease, and, as Robert Jenson observed, 'a condition of poverty and social collapse, more than a geographical place'. Through the 1960s, the Bronx's prefix was merely descriptive of the borough's southernmost neighbourhoods, like Mott Haven and Longwood. But now most of New York City north of $110^{\text {th }}$ Street was imagined as a new kind of 'South,' a global south just a subway ride away. ${ }^{151}$

This quote from Chang is reminiscent of the way Ted Gioia talked about "two Harlems" in the previous chapter. In this instance, however, it was the harsh material realities that gave the Bronx its symbolic power. Further, this reference to the "reconstructed South" brings to mind the ways in which borders are utilised in the construction of historical narrative. While often the origins of hip hop are attributed to the Bronx more generally, boundaries can be erected to further circumscribe the site of cultural memory, which in turn circumscribes the interpretive particularities of memory transferal.

\section{Space, Place, and Borders: Dub and Disco}

Of course, it wasn't just a book and a movie which fostered the enduring memory of the Bronx, South or otherwise. As already mentioned, on August 11, 1973, a musical moment supposedly initiated by Kool

\footnotetext{
147 Jeff Chang, Can't Stop Won't Stop: the History of the Hip Hop Generation (New York: St. Martins Press, 2005), 15.

148 Winnie Hu, 'Fighting the Image of the "Burning" Borough', The New York Times (07/2013), A13.

149 Roland Barthes, 125.

150 lbid.

151 Jeff Chang, Can't Stop Won't Stop: the History of the Hip Hop Generation (New York: St. Martins Press, 2005),
} 13. 
Herc ushered in a new genre, a genre we now refer to as hip hop. And hip hop, as Murray Forman points out, has exhibited a preoccupation for articulations of place since the very beginning. ${ }^{152}$ Grandmaster Flash, here quoted by Forman, recalls:

We had territories. It was like, Kool Herc had the west side. Bam had Bronx River. DJ Breakout had way uptown past Gun Hill. Myself, my area was like $138^{\text {th }}$ Street, Cypress Avenue, up to Gun Hill, so we all had our territories and we all had to respect each other. ${ }^{153}$

Here is perhaps the most localised case of a prevailing tendency within hip hop historiography: the invocation of borders. As has been discussed already with Chang and the Cross-Bronx Expressway, borders and boundaries make for useful discursive tools in mythical representation. When it comes to the construction of a master narrative, a narrative composed and reiterated in this context primarily from the 'founding fathers', separating the story into more readily digestible units makes for easier transmission ${ }^{154}$ and is thus more likely to be accepted as 'history.' In discussing myth and its relationship to physical places, it seems rather obvious that the boundaries between these places would come into play. With hip hop discourse in particular, with its emphasis on place, borders feature heavily. Murray Foreman suggests that:

there has been an enhanced emphasis on the powerful ties to place that both anchor rap acts to their immediate environments and set them apart from other environments and other 'hoods as well as from other rap acts and their crews which inhabit similarly demarcated spaces. ${ }^{155}$

But the notion of boundaries in this context is broader than the geographic separation of hip hop groups, as exemplified by Grandmaster Flash above. David Newman writes "the existence of territorial boundaries is taken as normative in the sense that the compartmentalisation of social, economic, and cultural space assumes the presence of lines that separate these spaces from each other." 156 The idea of the “assumption' of dividing lines is key here. These borders are not fixed, but are "continually open to negotiation and renegotiation. ${ }^{157}$ Boundaries then, are not neutral but are strategically deployed within the

\footnotetext{
152 Murray Forman, 'Represent,' in That's the Joint!: A Hip Hop Studies Reader, ed. Murray Foreman and Mark Anthony Neal (New York: Routledge, 2004), 202.

153 Ibid.

154 Scott DeVeaux, 'Constructing the Jazz Tradition: Jazz Historiography', Black American Literature Forum 25/3 (1991) 525-526.

155 Murray Forman, 'Represent,' in That's the Joint!: A Hip Hop Studies Reader, ed. Murray Foreman and Mark Anthony Neal (New York: Routledge, 2004), 204.

${ }^{156}$ David Newman, 'Boundaries, Borders, and Barriers: Changing Geographic Perspectives on Territorial Lines', in Identities, Borders, and Orders: Rethinking International Relations Theory ed. Mathais Albert, David Jacobson, and Yosef Lapid (Minnesota: University of Minnesota Press, 2001), 137.

${ }^{157}$ Murray Forman, 'Represent,' in That's the Joint!: A Hip Hop Studies Reader, ed. Murray Foreman and Mark Anthony Neal (New York: Routledge, 2004), 203.
} 
master narrative of hip hop. Furthermore, these borders are conceived of not just in terms of geography, but also genre. To destabilise the master narrative, therefore, such borders need to be broken down, or, at the very least resituated. The following section will look at the way borders have been utilised in the master narrative of the origins of hip hop, allowing the 'myth' to become the 'history.'

I have characterised a 'master narrative' as a story that, while composed of representations as with another depiction of that past, persists relatively unchanged thanks to frequent reiterations. Further, this narrative is all the stronger when such reiterations are exercised by the founding fathers, as is often the case with hip hop. Founding fathers, though their memories are subject to the same degree of transmutation as anybody else, are never-the-less the ideal source as far as 'history' is concerned, given their relative proximity to place of cultural memory. This I encountered first hand during my participation on the 'Hip Hop Origins Tour,' led by Grandmaster Caz. What was perhaps the most important stop on the tour was outside the apartments at 1520 Sedgwick Avenue, where Caz relayed the story of Herc's initial party on August 11, 1973. Caz himself was too young at the time to go to the party, but considering the other people on the tour were a German family and an Australian couple in their 20s, he was temporally, culturally, and geographically closer to the initial context, and so was less dependent on myth and so in a position of greater authority. In effect he had agency over determining which sites were more, or less, important in the narrative he is invested in. Given that the tour occurs multiple times per week, this invocation of the border between pre-breakbeat and post-breakbeat is reiterated enough on the tour alone to enshrine it with the status of 'master narrative.'

But Jennifer Frost and Hayden White have already alluded to agency inherent within the construction of history, and so such an approach it tantamount to the reiteration of myth. Mark Katz, having previously offered a reiteration of the abovementioned border, goes on to say:

Origin stories aren't like birth certificates; their significance lies not in the facts they disclose but in the values they reveal. And what this origin story reveals is the veneration of the pioneer, the visionary who forges a new path. ${ }^{158}$

\section{$\underline{\text { Dub in New York }}$}

In this quote, Katz is admitting that the origin story is a myth as I have applied it through the thesis. The invocation of that particular border, therefore, is not arbitrary but intimately tied to the mythologised status of Kool Herc. Even when some commentators set the start date somewhat earlier, as Alex Ogg and David Upshal did when they argued that "to all intents and purposes, hip hop started the day Jamaican-

${ }^{158}$ Mark Katz, Groove Music: the Art and Culture of the Hip Hop DJ (New York: Oxford University Press, 2012), 23. 
born Clive Campell, aka Kool Herc, first set foot in New York in 1967." ${ }^{159}$ It is still dependent on the mythical power of this founding father of founding fathers; as was the case with Buddy Bolden in New Orleans, we are led to believe that hip hop can be neatly traced back to not only a singular place, but to a singular individual. That said, proponents of the Kool Herc-as-creator narrative can make a fairly strong case. As Chang points out, Herc was born and raised in Trenchtown, Jamaica "in the same Second Street yard that had produced Bob Marley." 160 Yet again, we are confronted with a mythologised image of place; thanks to the international scope of the musical efforts of Bob Marley, Herc's status is further strengthened by the fact that they happened to share a point of origin, despite the considerable difference in age and musical direction. In fact Chang, following from comments from Herc himself, goes so far as to suggest that hip hop started in Trenchtown, not the Bronx. ${ }^{161}$ This is an interesting counter-myth to the South Bronx narrative, and there were certainly musical and cultural precedents that support such an argument, as will become clear.

A lingering question remains, however, concerning the extent to which such a stance was influenced by Herc stating "Them said nothing good came outta Trenchtown. Well, hip hop came out of Trenchtown!" 162 As the foremost founding father, Herc had greater agency in shaping the ensuing narrative than others, and so his statements carried greater weight. As a Jamaican native, it stands to reason he had a vested interest in controlling cultural memory, shifting remembrance to the country of his birth. Again, while this is statement steeped in myth, it is not without its credibility. The history of music making in Jamaica, particularly during the so-called 'dub revolution,' which incidentally was happening around the same time as Herc immigrated to the Bronx, shares several characteristics with early hip hop practices, emphasising the somewhat mutable border between these genres, particularly when applied to a New York context. One key characteristic is the playful appropriation of technology originally intended for musical reception. ${ }^{163}$ Due in part to reasonably impoverished economic conditions, these dub revolutionaries would take old ska and rocksteady records and refashion them into something that, while familiar, was fundamentally different. As Lloyd Bradley explains:

Dub is part of this astonishing capacity for recycling. It involves taking either the recent or the ancient past (in reggae terms, six months ago can be prehistoric), and refashioning it to fit the contemporary requirements in the present. Duke Reid and U-Roy did it with a bunch of old rocksteady songs, just as Justin Hinds and the Dominoes re-trod 'Carry Go Bring Come' in both ska and rocksteady (coincidentally, another Duke Reid production); and Bob Marley wasn’t above redeploying the Wailers’ 1971/72 Lee Perry sessions

\footnotetext{
159 Alex Ogg, David Upshal, The Hip Hop Years: A History of Rap, (London: Macmillan Publishers Ltd, 1999$), 13$.

160 Jeff Chang, Can't Stop Won't Stop: the History of the Hip Hop Generation (New York: St. Martins Press, 2005), 24.

161 Jeff Chang, Can't Stop Won't Stop: the History of the Hip Hop Generation (New York: St. Martins Press, 2005), 24

162 Ibid.

163 Lloyd Bradley, Bass Culture: When Reggae Was King (London: Penguin Books Ltd, 2000), 310.
} 
as late as his 1978 Kaya album. You could say its part of a national tradition dictated by the fact that, when you can't afford to throw much away, things have to be recyclable. ${ }^{164}$

Pre-existing records, once considered as artefacts of consumption, became the raw materials for a new brand of musical expression. But this new medium needed a vehicle for its dissemination. That vehicle was found in the sound system, the other crucial component of the dub revolution. For such a small island, Jamaica boasted an impressive amount of systems by the mid to late 1960s, such as Downbeat, Treasure Isle, Lloyd the Matador, and the Supreme Ruler of Sound. ${ }^{165}$ But it was arguably Tubby's Home Town HiFi, assembled by engineer King Tubby, which led the pack. Dennis Alcapone, here quoted by Bradley, remembers:

King Tubby had a sound system that I never hear nothing like it in my whole life. Sound systems, the big ones, was always exciting, but when Tubby came one the scene it was extraordinary (emphasis in the original). Jammy's was a round in those days, it had been there for a long time, but it was like King Tubby's Part Two, it was never up there with Tubby's. Most of these dances we talking about were outdoor things, where you always have the big speaker boxes, but Tubby had him steel horns for the treble and he put them up in the trees so it's like the sound is coming from all over. When the night was warm, the breeze is blowing and the music's playing, it's truly something to behold. King Tubby's sound system was definitely magic. ${ }^{166}$

Anyone familiar with the characteristics that supposedly defined early hip hop - appropriating technologies of reception, outdoor dance parties, sound systems battling for supremacy - should recognise the similarities, and so Herc's assertion that hip hop originated in Trenchtown is not so easy to dismiss. But, as we've seen already, when Jamaica is mentioned in the discussion it tends to focus around the fact that Herc was from there. This is not to suggest that the country of his birth had no concrete bearing on his musical development. Indeed, Herc recalled that:

There was a lot of big sound systems they used to pick up and play on the weekends. I was a child, ya know, lookin', seein' all these things going on, and sneakin' out of my house and seein' the big systems rattling the zincs on the housetops and stuff. ${ }^{167}$

While it is certainly likely that Herc would have experienced such things in his childhood, it should be reiterated that much of our understanding of the history of hip hop, or any narrative for that matter, is intimately dependent on personal remembrances such as this. Cultural memory, or agreed upon impressions of the past, are first and foremost constructed on the basis on individual memories. This cultural memory, which is so crucial to the formation of collective identity, is thus at the mercy of the dubious nature of the anecdote. This is the second strategy, along with the invocation of borders, which actors can use to counteract the myth making model I've outlined in the thesis. Malina Stefanovska

\footnotetext{
164 Lloyd Bradley, Bass Culture: When Reggae Was King (London: Penguin Books Ltd, 2000), 310.

165 Ibid., 311.

${ }^{166}$ Ibid., 314.

${ }^{167}$ Mark Katz, Groove Music: the Art and Culture of the Hip Hop DJ (New York: Oxford University Press, 2012$), 26$.
} 
argues that the anecdote, particularly when attributed to founding fathers, satisfies the readers "voyeuristic" tendencies, ${ }^{168}$ we are led to believe we are gaining a sneak peak into our mythologised hero's private world. She goes on to suggest that, like borders, the incorporation of anecdotes into historical narrative makes them easier to teach. ${ }^{169}$ According to Mark Katz, Herc did go on to put together the biggest system in the Bronx, which does suggests that some of the sentiments and practises he supposedly experienced in Jamaica rubbed off on him, but Amir Said reminds us that Herc hadn't yet reached his teens when he reached the Bronx, and wouldn't yet resemble a DJ for another 5 years. ${ }^{170}$ Moreover, this was an anecdote recalled many years later, when Herc was already recognised as the primary founding father. Keeping in mind my conception of distance and its relationship to the mythmaking process, the sheer difference in time between the lived experience and the recollection implies sufficient distance for the memory to degrade. Further, the memory itself needed to travel through multiple liminal spaces for it to shift from his memory banks to more far-reaching modes of mythical speech, opening up possibilities for further erosion and transmutation. Regardless of strategy therefore, the model proposed is always in effect. What's more, Herc's aforementioned position as the foremost founding father at the time of the remembrance implies a need to legitimise that position; providing a direct link to the rich history of Jamaican sound system culture is one way of achieving just that.

Further problematizing this position is the simple fact that, obviously, Herc was not the only immigrant from the Caribbean to find their way to New York. Mark Katz points out that mobile sound systems, an integral feature of early hip hop DJ battles as well as Jamaican sound system clashes, were in operation as early as $1959 .{ }^{171}$ One such exponent was King Charles who, like Herc, moved to New York from Jamaica in 1968. ${ }^{172}$ Unlike Herc, however, King Charles settled in Queens. As the moniker suggests, King Charles was deeply rooted in the Jamaican DJ tradition; he assembled a massive, but mobile, sound system, and would hire the best DJs around the neighbourhood to showcase his reggae and dub collection. ${ }^{173}$ It is this last point that arguably best explains his absence from conventional narratives; King Charles resembled the Jamaican "selector" more than the hip hop DJ. Grandmaster Caz, in a personal interview at his home in the Bronx, elaborates:

\footnotetext{
168 Malina Stefanovska, 'Exemplary or Singular: The Anecdote in Historical Narrative', SubStance 38/1 (2009), 17. 169 Ibid., 21.

${ }_{170}$ Mark Katz, Groove Music: the Art and Culture of the Hip Hop DJ (New York: Oxford University Press, 2012$), 27$. 171 Ibid.

172 Hassan Pore, Ron Lawrence, Founding Fathers: the Untold Story of Hip Hop, HighLife Entertainment (2009). 173 Ibid.
} 
Caz: You know the name is not coming to me but that bought some clarity to it when you said he wouldn't play the records he'd give the DJ the record to play, know what I mean. Cause in Jamaican DJ culture, the DJ isn't the guy playing the records, the DJ is the guy on the mic.

Me: Ah it's so interesting those different uses of the word DJ and how its changed over time, you'd never call, if you were talking about EDM, something like that, you'd never call someone a DJ unless they actually did it themselves

Caz: Jamaican DJ culture, I mean hip hop is sort of a derivative of the Jamaican DJ culture....

Me: Yeah like the sound systems..

Caz: The sound systems, exactly. You got.the guy on the mic is the DJ, and he doesn't rap, or rhyme, he toast. Toasting, that's what they call that. And the guy playing the records is the selector.

Me: Right yes "easy selector," I've heard that phrase

Caz: Right right, he selects the records, so so hip hop DJ culture kind of mirrors it but its opposite. ${ }^{174}$

Though Grandmaster Caz touches on their relatedness, he also clearly differentiates the two, thus maintaining the border. Rather than spin the records, he would choose which record would come next, passing it to whichever DJ was operating at the time. Despite these admittedly crucial performative differences, the work of someone like King Charles reinforces the fact that big, bass-heavy sound systems were pumping all over the New York area, not just the Bronx. Furthermore, to bring him in to the discussion is to challenge Herc's status as the convenient linking figure between Jamaican sound system culture and hip hop.

\section{Hip Hop and Disco: Forgotten Links}

Another New York-based sound that shared certain performative similarities was disco. Like hip hop, this was a dance based music which involved innovative usage of technology in an urban, disenfranchised context. It is perhaps this last point that is most relevant to the present discussion. In his book Turn the Beat Around: The Secret History of Disco, Peter Shapiro opens with the following:

Disco was the height of glamour and decadence and indulgence. But while disco may have sparkled with diamond brilliance, it stank of shit. Whatever its veneer of elegance and sophistication, disco was born, maggot-like, from the rotten remains of the Big Apple. In the early 70s 'New York City' became a shorthand for everything that was wrong with America. Movies like Midnight Cowboy, French Connection, Taxi

${ }^{174}$ Grandmaster Caz, Interview in the Bronx (17 February 2015). 
Driver, Panic in Needle Park, Prisoner of Second Avenue, the Out-of-Towners, Dog Day Afternoon, Shaft, Across $110^{\text {th }}$ Street, and Death Wish depicted a city on the brink: a cesspool of moral and spiritual degradation, a playground for drug dealers, pimps, and corrupt cops. ${ }^{175}$

As we can see from this colourful and evocative quote, Shapiro is framing his discussion on disco in the same vein as commentators discuss hip hop. As with Alain Locke in the previous chapter, the language used here is deployed to stimulate an emotional response on behalf of the readers; we are compelled to be drawn in to the story he wishes to tell. And like Winnie Hu of the New York Times writing about the continued negative topology of the Bronx, Shapiro touches on how the topology of a place can be affected by media representation, only in this instance he isn't referring to the Bronx, but to New York more broadly. This is a crucial point when considering myth and its relationship to physical places. Going back to Lincoln, he argued that the target social grouping for a given myth can be broadened or localised, depending on the myth. What's useful about mythologizing geographical places is that the myth maker can make use of pre-existing borders; by widening the scope somewhat, Shapiro makes use of a similar myth as that of Chang to tell a very different story. At this point, it is also worth reiterating the importance of this last word, 'story.' As has already been touched on, a consistent theme in various academic definitions of myth is its dissemination in the form of narrative. Don Cupitt, here quoted by Laurence Coupe, suggests:

The work of myth is to explain, to reconcile, to guide action or to legitimate. We can add that myth making is evidently a primal or universal function of the human mind as it seeks a more or less unified vision of the cosmic order, the social order, and the meaning of the individual's life. Both for society at large and for the individual, this story generating function seems irreplaceable. The individual finds meaning in his life by making of his life a story set within a larger social and cosmic story. ${ }^{176}$

Thus when Shapiro waxes lyrical about the environmental context which bought about disco, he is doing more than just 'stating the facts.' Considering the book was released in 2005, Shapiro was able to make use of 30 odd years' worth of compounded representations of 1970s New York, implying that perhaps there was now enough distance to appropriate the myth of the Bronx and apply it to the whole city.

To be fair to Shapiro, he does make specific reference to various incidents that occurred throughout the city, including the arson that plagued the South Bronx. ${ }^{177}$ So perhaps it was the other way around, perhaps Chang et al were localising the myth, focusing on conditions of the Bronx specifically to enrich the story of the origin of hip hop. Indeed, Chang is far from the only commentator to draw on the aforementioned boundaries (genre and geography) to shape the ensuing narrative. Another documentary, The Hip Hop

\footnotetext{
175 Peter Shapiro, Turn the Beat Around: the Secret History of Disco (London: Faber and Faber Ltd, 2005), ix.

176 Laurence Coupe, Myth (London: Routledge, 1997), 6.

177 Peter Shapiro, Turn the Beat Around: the Secret History of Disco (London: Faber and Faber Ltd, 2005), xiii.
} 
Years, places hip hop, and its' supposed point of origin, in direct opposition to Disco. ${ }^{178}$ While it does offer the obligatory nod to the development of mixing records, disco's flagship performative development, Disco is presented as an exercise in crass, commercialised hedonism. Scenes of predominately white and discernibly square dancers bathed in flashing lights accompany the sound of Sister Sledge's 'We Are Family,' creating an image of frivolous fodder for the middle-class of midtown Manhattan. This image is then directly contrasted with hip B-Boys, presumably in the Bronx, showcasing their talents; it is painfully clear to the audience, therefore, which of the two is 'cooler' than the other. It would not be too much of a stretch to assume that the former is the prevailing image of disco in most people's minds, particularly those who were not yet alive during its heyday. Indeed, while such films as Fort Apache: The Bronx and Across $110^{\text {th }}$ Street helped manipulate the cultural memory of the Bronx (or, for Shapiro, New York City more generally), Saturday Night Fever had a similar effect for disco. Not only did it aid in spreading disco fever from the confines of the city to the main stream - as John-Manuel Andrionte remembers, "everybody thought disco was just for gay guys and black folks. John Travolta showed them that straight white guys can like disco" 179 - it also solidified certain visual tropes that continued to circulate in popular media, from the dancing sequence in Airplane! to 'The Simpsons' sidecharacter Disco Stu. ${ }^{180}$ It was this image of disco, the "big ball room floors, the style of dress, that opulence, that Mick Jagger/Bianca Jagger studio 54 thing" ${ }^{181}$ as Grandmaster Caz put it, that established hip hop heavy-weights were evidently trying to align themselves against. Here again is an example of where the distinction between 'myth' - as it's been defined previously- and 'history' becomes uncertain. While documentaries like The Hip Hop Years and books such as Cant Stop Won't Stop: The History of the Hip Hop Generation are ostensibly 'history' insofar as they attempt to relay events from the past, they never the less draw on paradigmatic truths; conceptual lines in the sand are drawn between disco and hip hop, and the Bronx and the rest of New York.

\section{Disco and Hip Hop Come Together}

As with most borders, particularly conceptual ones, the line between disco and early hip hop is far from distinct. Indeed, several DJs, again drawn from Founding Fathers: the Untold Story of Hip Hop, existed in the grey area between the two, sharing several performative characteristics, but operating primarily outside the Bronx. The Disco Twins, based in Queens, are one such example. Their name of course, confuses the issue somewhat. But according to Founding Fathers: the Untold Story of Hip Hop, the Disco

\footnotetext{
178 David Upshal, The Hip Hop Years (1999).

179 John-Manuel Andrionte, Hot Stuff: A Brief History of Disco (New York: HarperCollins Publishers Inc., 2001$), 8$.

180 Alan Jones and Jussi Kantonen, Saturday Night Forever: The Story of Disco (Great Britain: Mainstream Publishing Company, 1999), 143.

${ }^{181}$ Grandmaster Caz, Interview in the Bronx (17 February 2015).
} 
Twins were primarily outdoor DJs with "one of the top systems in the country. Not in the city, not in the state, in the country." " 182 What's more the twins were known to incorporate tricks into their performances, in a more rudimental version the kind of thing Grandmaster Flash would eventually become known for. ${ }^{183}$ Alex Ogg and David Upshal actually reference the Disco Twin's sound system, ${ }^{184}$ in what amounts to be a rare citation indeed. However, they make the point that the Twins didn't play anything outside of Disco tracks until the 1980s, a performative point of difference that amounts to a conceptual border.

Grandmaster Caz makes a similar point in the following passage:

Caz: It is like a thin line, but there's a line ok because people like the disco twins... and the disco twins are more toward the hip hop side, like the line is blurred where the disco twins are but people that preceded the disco twins, Plumber, Natoya, Pete DJ Jones, these were guys playing in the tradition of the hip hop DJ but they were playing completely different music. These were those house party DJs, these were those block party DJs who would play the music of the day, which was disco.

Me: Disco.

Caz: you know what I mean, you look in these guys crates for records, disco, disco, disco. Sure some 60s and $70 s R \& B$ and stuff but mainly, that was their playlist, disco.

Me: Yeah that's what I'd heard...

Caz: Nobody was scratching, nobody was manipulating records besides just putting it on and playing it.

Me: Yeah that's what I heard. I mean one of major innovations that people point toward Kool Herc for is the isolation of the break beat, and mixing the break beat into another beat as opposed to a track into another track. And this is one of the reasons why people say it started in the Bronx because of that one particular innovation.

Caz: Yeah. They played records, we played sections of records. We had a whole continuum of music that you never even heard the rest of the song, all you heard was that part of the song, and that created a whole new genre. You know what I mean, like you and I can play the same record but you put it on in the beginning and I'm playing it when it goes BAM! Haha and that's the record to us. Not the intro, not the melody, this is the record for us. And that's the definitive difference between disco and hip hop, you know what I mean, even though hip hop... derived from the influences that came before it. I've been quoted in movies saying hip hop didn't invent anything, hip hop re-invented everything. So whatever was being

\footnotetext{
182 Hassan Pore, Ron Lawrence, Founding Fathers: the Untold Story of Hip Hop, HighLife Entertainment (2009).

${ }^{183}$ Alex Ogg, David Upshal, The Hip Hop Years: A History of Rap, (London: Macmillan Publishers Ltd, 1999$), 27$.

184 Ibid., 31.
} 
done at the time, we put a new twist on it, ok, we put a new twist on it. You guys want to play records at parties, ok we're going to play records too but we going to do it like this, and we're only going to play this part of the record. And that creates a whole other division, you understand what I'm saying?

Although it's plain to see that Caz is aware that is too simplistic to completely separate the two genres, this reference to "a thin line" and "a whole other division" is suggestive of the invocation of borders. The master narrative of hip hop, though contested by the Founding Fathers documentary, survives relatively unscathed through this process. Though the anecdote, a subjective remembrance transmitted in the form of a narrative, is no more immune to distortion or degradation than any other memory, the fact that in this instance they come from mythologised founding fathers engages the reader and helps to offset the mythmaking model. This process, combined with circumscribing the narrative through boundaries allows the 'myth' of the origins of hip hop to become, for all intents and purposes, the history.

\section{Conclusion:}

This chapter examined how those closest to the context in which music arises are able to actively manipulate the historical narratives that emerge from their efforts. Through the frequent reiteration of a familiar narrative with a dubiously specific starting point, the 'founding fathers' attempt to counteract the vagaries of memory. This is facilitated through their relative proximity to the area and is achieved through interviews with people such as myself, through documentaries, and specific origin tours. This is not to suggest that memory transferal through such an approach will not eventuate in some distortion, but the familiarity evident through each iteration arguably keeps it to a minimum.

The other strategy employed in controlling cultural memory is the constitution (or reconstitution) of borders. Whether in terms of genre or geography, or in this case both, invoking borders circumscribes the eventual narrative in much the same way that distinctions between chronological eras do. Again the agency implied in such processes illustrates the similarity between myth and history. 


\section{Final Conclusion}

This thesis has aimed to explore notions of myth and its relationship to history and memory. Through a focus on physical places and the musical narratives that come out of them I have looked to provide a model that may make sense of how myth is constructed, and potential methods deployed to counter-act it. In the introduction I provided the theoretical framework that informed said model, namely the interplay between myth, history, memory and liminality. I argued, and I reiterate here, that 'myth' and 'history' are not separate concepts, but are intimately related ideas.

That they are difficult to distinguish is due in part because of their presentation in the form of an edited narrative. Hayden White and Jennifer Frost shed light on how any narrative pertaining to past events involves strategic decision making, and are thus evaluative gestures. Myth, according to the likes of Christopher Small and Bruce Lincoln, is not necessarily that which is false, but rather a rendering of the past to cater to present day values and sensibilities. Moreover, Roland Barthes characterises myth as a type of speech, a message. This message can take on a variety of forms, but most crucial to the present discussion is the form of the historical text. Any book that claims to detail the 'history' of a given subject, therefore, amounts to a 'freezing', and subsequent dissemination of mythical representation. These points alone reveal just how strikingly similar they are in form and function, but I also argue that just as importantly, they both necessarily share the same raw materials: individual memories.

Johannes Fabian, Maria G. Cattell, Jacob J. Climo, and Astrid Errl characterise memory as prone to various forms of transmutation. Whether by conscious and deliberate re-remembering or more passive distortion and degradation, memories are not a pure recollection of that which has happened, but a representation of that which has happened. These individual memories come together to foster cultural memory, or "agreed upon impressions" of the past. Once again a definition reminiscent of myth.

It is when these remembrances travel through liminal space that myth making occurs. A term borrowed from anthropology, liminality in this context refers to the transformative thresholds in which memories travel though, opening themselves up for all manner of distortive possibilities. Taken together, these concepts constitute my proposed theoretical model: impressions of the past rely on subjective remembrances traveling through liminal space from one person to the next, fostering a series of compounding representations that can transform at any one of the many liminal points along the way. The further down the line one is, the more one is dependent of mythical representation. Any impression of the 
past, whether deemed 'history' or 'myth' must go through this process and thus an objective account of the past is impossible.

In Chapter One I elaborated upon this idea of distance and the 'master narrative.' I argue that once a given narrative becomes enshrined within the pages of a history book, it allows the narrative a more farreaching scope, creating more liminal spaces as the potential audience grows. The emotive language applied in those pages has the effect of suspending a representation of a physical place in a mythologised realm of cultural memory, removed from the context in which it arose. This introduces my conception of distance. Along with the distance implied in liminal spaces, distance in this context refers to a somewhat less abstracted proximity to the site of cultural memory. Whether geographically, culturally, or temporally, the greater the distance, the more mythologised the site becomes. Unlike the latter two, physical distance is a relatively easy gulf to collapse, emphasising the utility of a focus on locality.

The second chapter then looked at how actors invested in the 'master narrative' of the origins of hip hop may be able to circumscribe the transformative potential of the model outlined above. One such method was 'founding fathers' frequent reiterations in interviews, documentaries, tours, and the like of the same narrative. If one applies my conception of distance, 'founding fathers' were and are closer in all three respects, physically, culturally, and temporally. Their remembrances therefore, arguably carry more weight as they are less dependent on compounding representation. After all, it is from their own memories, their own anecdotes, that the master narrative arose. This is not to say that this presentation of the past is not mythical, as many such anecdotes were recalled many years later. Further, as potential originators of a now global phenomenon, they arguably had a certain motivation for keeping the narrative as consistent as possible.

Another strategy is the invocation of borders, physical as well as musical. As demonstrated by the contrasting, and yet similar narrative tactics between Chang and Shapiro, as well as the remembrances of the likes of Kool Herc and Grandmaster Caz, the invocation of boundaries circumscribes the narrative, creating a more discreet genre while simultaneously creating a more discrete environmental context. The moment Herc discovered the breakbeat provided a convenient chronological border, but it also fostered a boundary distinguishing what would become hip hop from Dub and Disco, the Bronx from the rest of New York, and the man himself from figures such as King Charles or the Disco Twins.

Though my focus in this instance was on the myth of physical places and the gestures that manipulate them, I believe that the model I have proposed has more far reaching implications. Place was a valuable case study as it provided me with an opportunity to tease out my contention that a broad conception of distance from the site of cultural memory dictates how dependent one is on myth, but the idea that 
information we inherit amounts to compounding representations applies to wider fields of inquiry. Neutral accounts of anything are virtually impossible. It has already been established that the distinction between myth and history is problematic, but I have taken it one step further. Since both history and myth are constructed from compounding subjective memories that travel through an unknowable number of liminal points, both are entirely dependent on representation. In fact, to knowingly label a collection of ideologically imbued memories as 'history' would in essence only serve to further cultivate a myth of objectivity. The 'myth' of Harlem and the 'myth' of the Bronx serve to draw attention to, among other things, the myth of 'history.' 


\section{Bibliography:}

Adams, Michael Henry. Harlem, Lost and Found: An Architectural and Social History 1765-1915. New York: Monacelli Press, 2002.

Anderson, Paul Allan. Deep River: Music and Memory in Harlem Renaissance Thought. Durham \& London: Duke University Press, 2001.

Andrionte, John-Manuel. Hot Stuff: A Brief History of Disco. New York: HarperCollins Publishers Inc., 2001.

Archibald, Robert. 'A Personal History of Memory'. In Social Memory and History: Anthropological Perspectives, ed. Maria G. Cattel, Jacob J. Climo. California: Altamira Press, 2002), 65-81.

Areavibes.com. http://www.areavibes.com/new+york-ny/harlem/cost-of-living/. Accessed 7/02/2016.

Baraka, Amiri. Blues People: Negro Music in White America. New York: Morrow Quill Paperbacks, 1963.

Blesh, Rudi. Shining Trumpets: A History of Jazz. New York: De Capo Press Inc.,1946.

Bradley, Lloyd. Bass Culture: When Reggae Was King (London: Penguin Books Ltd, 2000), 310.

Brown, Peter. Interview at Lincoln Centre. 7 February 2015.

Cattell, Maria G., Climo Jacob J. 'Meaning in Social Memory and History'. In Social Memory and History: Anthropological Perspectives, ed. Maria G. Cattel, Jacob J. Climo. California: Altamira Press, 2002. 1-39

Caz, Grandmaster. Interview in the Bronx. 17 February 2015.

Chang, Heewon. Autoethnography as Method. California: Left Coast Press Inc., 2008.

Chang, Jeff. Can't Stop Won't Stop: the History of the Hip Hop Generation. New York: St. Martins Press, 2005.

Charters, Samuel. A Trumpet Around the Corner: the Story of New Orleans Jazz. Mississippi: University of Mississippi Press, 2008.

Collins, Peter. Gallinat, Anselma. 'The Ethnographic Self as Resource: An Introduction'. In The Ethnographic Self as Resource: Writing Memory and Experience into Ethnography, ed. Peter Collins and Anselma Gallinat. (New York: Berghahn Books, 2010), 1-25 
Coupe, Laurence. Myth. London: Routledge, 1997.

Davis, Arthur P. 'The Harlem of Langston Hughes' Poetry'. Phylon (1940-1946) 13/4 (1952), 276-283.

Davis, Charlotte Aull. Reflexive Ethnography: A Guide to Researching Selves and Others. London: Routledge, 1999.

DeVeaux, Scott. The Birth of Bebop: A Social and Musical History. California: University of California Press, 1997.

DeVeaux, Scott. 'Constructing the Jazz Tradition: Jazz Historiography'. Black American Literature Forum 25/3 (1991) 525-560.

Dolkart, Andrew S. Sorin, Gretchen Sullivan. Touring Historic Harlem: Four Walks in Northern Manhattan. New York: New York Landmarks Conservancy, 1999.

Ellis, Carolyn. The Ethnographic I: A Methodological Novel about Autoethnography. Lanham: Altamira Press, 2004.

Errl, Astrid. 'Cultural Memory Studies: An Introduction'. In Cultural Memory Studies: an International and Interdisciplinary Handbook, ed. Astrid Erll, Ansgar Nünning. Berlin: Walter de Gruyter GmbH \& Co., 2008. 1-19.

Fabian, Johannes. 'Ethnography and Memory'. In Ethnographic Practice in the Present, ed Marit Melhuus, Jon P. Mitchell, and Helena Wulff. New York: Berghahn Books, 2010. 16-28.

Fabian, Johannes. Memory Against Culture: Arguments and Reminders. Durham: Duke University Press, 2007.

Floyd Jr, Samuel. Black Music in the Harlem Renaissance: A Collection of Essays. California: University of Tennessee Press, 1993.

Foreman, Murray. 'Represent'. In That's the Joint!: A Hip Hop Studies Reader, ed. Murray Foreman and Mark Anthony Neal. New York: Routledge, 2004. 201-223.

Frost, Jennifer 'Using "Master Narratives" to Teach History: The Case of the Civil Rights Movement'. The History Teacher 45/3 (2012), 437-446

Geertz, Clifford. The Interpretation of Cultures: Selected Essays. New York: Basic Books, 1973.

Gendron Bernard. 'Moldy Figs and Modernists: Jazz at War (1942-1946)'. In Jazz Among the Discourses, ed. Krin Gabbard. Durham: Duke University Press, 1995. 31-57. 
Gennari, John. Blowin' Hot and Cool: Jazz and its Critics. Chicago: University of Chicago Press, 2006.

Gioia, Ted. The History of Jazz. New York: Oxford University Press, 1997.

Hu, Winnie. 'Fighting the Image of the "Burning” Borough'. The New York Times, 07/2013. A13.

Jones Alan. Kantonen, Jussi. Saturday Night Forever: The Story of Disco. Great Britain: Mainstream

Publishing Company, 1999.

Katz, Mark Groove Music: the Art and Culture of the Hip Hop DJ. New York: Oxford University Press, 2012.

Kmen, Henry A. 'The Roots of Jazz and the Dance in Place Congo: A Re-Appraisal'. Anuario Interamericano de Investigacion Musical 8 (1972). 5-16

Lincoln, Bruce. Discourse and the Construction of Society. Chicago: University of Chicago Press, 1987. Lott, Eric. 'Double V, Double-Time: Bebop's Politics of Style'. Callaloo 36 (1988). 597-605

Meneley Anne. Donna J. Young. 'Introduction - Auto-Ethnographies: The Anthropology of Academic Practices'. In Auto-Ethnographies: The Anthropology of Academic Practices, ed. Anne Meneley and Donna J. Young. Toronto: Broadview Press Ltd., 2005.1-23.

McCullagh, C. Behan. 'The Truth of Historical Narratives'. History and Theory 26/4 (1987), 30-46.

Newman, David. 'Boundaries, Borders, and Barriers: Changing Geographic Perspectives on Territorial Lines'. In Identities, Borders, and Orders: Rethinking International Relations Theory, ed. Mathais Albert, David Jacobson, and Yosef Lapid. Minnesota: University of Minnesota Press, 2001. 137-152.

Ogg, Alex, Upshal, David. The Hip Hop Years: A History of Rap. London: Macmillan Publishers Ltd, 1999.

Oliver, Paul 'Savannah Syncopators: African Retentions and the Blues,' in Yonder Come the Blues. Cambridge: Cambridge University Press, 1970.

Orwell, George. 1984. New York: Penguin Books,1949.

Peretti, Burton W. The Creation of Jazz: Music Race and Culture in Urban America. Chicago: University of Illinois Press, 1992.

Pore, Hassan. Lawrence, Ron. Founding Fathers: the Untold Story of Hip Hop. HighLife Entertainment. 2009. 
Radvansky, Gabriel A. Krawietz, Sabine A. Tamplin, Andrea K. 'Walking Through Doorways Causes Forgetting: Further Explorations'. The Quarterly Journal of Experimental Psychology 64/8 (2011), 16321645.

Ramsey, Guthrie P. Race Music: Black Cultures from Bebop to Hip Hop. California: University of California Press.2003.

Shapiro, Peter. Turn the Beat Around: the Secret History of Disco. London: Faber and Faber Ltd, 2005.

Turner, Victor. 'Betwixt and Between: The Liminal Period in Rites of Passage'. In Betwixt and Between:

Patterns of Masculine and Feminine Initiation, ed. Louise Carus Mahdi, Steven Foster, and Meredith Little. Illinois: Open Court Publishing Company, 1987. 3-23.

Widmer, Ted. 'The Invention of a Memory: Congo Square and African Music in Nineteenth-Century New Orleans'. Revue française d'études américaines 98/2 (2003). 69-78

Wiesel, Elie. 'Myth and History'. In Myth, Symbol, and Reality, ed. Alan M. Olson. Indiana: University of Notre Dame Press, 1980. 20-31. 